\title{
A Study of Boratriazaroles-an Underdeveloped Class of Heterocycles
}

\author{
${ }_{2}$ Sean K. Liew, Aleksandra Holownia, Andrew J. Tilley, Elisa I. Carrera, Dwight S. Seferos,* and \\ ${ }_{3}$ Andrei K. Yudin* \\ 4 Davenport and Lash Miller Chemical Laboratories, Department of Chemistry, University of Toronto, 80 Saint George Street, \\ 5 Toronto, Ontario M5S 3H6, Canada
}

\section{S Supporting Information}

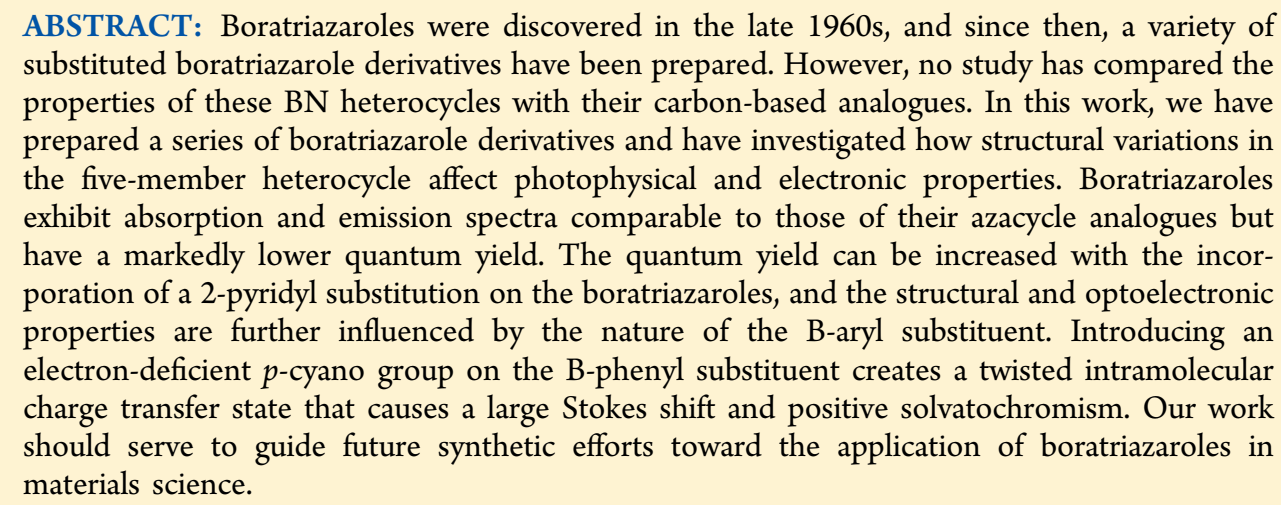
substituted boratriazarole derivatives have been prepared. However, no study has compared the properties of these $\mathrm{BN}$ heterocycles with their carbon-based analogues. In this work, we have prepared a series of boratriazarole derivatives and have investigated how structural variations in the five-member heterocycle affect photophysical and electronic properties. Boratriazaroles exhibit absorption and emission spectra comparable to those of their azacycle analogues but have a markedly lower quantum yield. The quantum yield can be increased with the incorporation of a 2-pyridyl substitution on the boratriazaroles, and the structural and optoelectronic properties are further influenced by the nature of the B-aryl substituent. Introducing an electron-deficient $p$-cyano group on the B-phenyl substituent creates a twisted intramolecular charge transfer state that causes a large Stokes shift and positive solvatochromism. Our work should serve to guide future synthetic efforts toward the application of boratriazaroles in materials science.

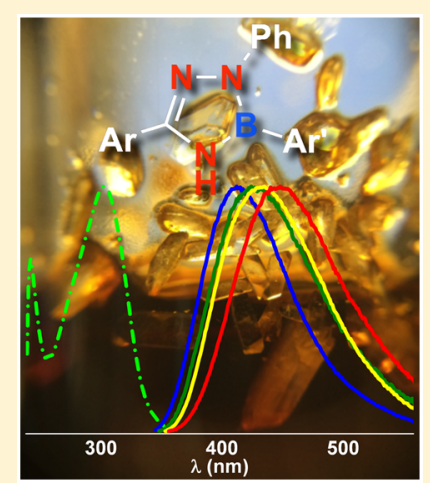

\section{INTRODUCTION}

21 The synthesis and study of boron-containing heterocycles 22 has become an active area of research. ${ }^{1,2}$ A common approach 23 to incorporate boron into heterocycles is to substitute $\mathrm{C}=\mathrm{C}$ 24 functionality with the isosteric and isoelectronic $\mathrm{B}-\mathrm{N}$ 25 moiety. ${ }^{3,4}$ When $\mathrm{B}-\mathrm{N}$ functionality is incorporated into aro26 matic heterocycles, some degree of aromaticity is retained. ${ }^{5}$ 27 The diversity of new aromatic B-N-containing heterocycles 28 imparts new intermolecular interactions and changes in photo29 physical properties, which can be exploited in areas such as 30 optoelectronics $^{6-8}$ and drug discovery.

31 In 1926, Stock and Pohland reported the first example of 32 interchanging $\mathrm{C}=\mathrm{C}$ with $\mathrm{B}-\mathrm{N}$ with their synthesis of borazine, 33 the $\mathrm{BN}$ analogue of benzene. ${ }^{10}$ Over the past decade, many 34 advances in the synthesis of new aromatic B-N-containing het35 erocycles have been achieved. ${ }^{5-9,11-13,42,43}$ Despite the vast 36 amount of research dedicated to exploring the ramifications 37 of $\mathrm{C}=\mathrm{C}$ to $\mathrm{B}-\mathrm{N}$ substitutions, 5-member aromatic boron38 containing heterocycles, ${ }^{14-27}$ such as boratriazaroles, ${ }^{28-37}$ have 39 not been fully explored. Boratriazaroles are B-N isosteres of 40 imidazoles and pyrazoles, two azacycles that are important 41 scaffolds in the pharmaceutical and agrochemical industry, ${ }^{38}$ 42 and have various applications in materials science. ${ }^{39-41}$ The 43 first documented boratriazarole synthesis was by Paetzold, who 44 reported only a $5 \%$ yield of the desired product. ${ }^{28}$ In 1971, 45 Dewar synthesized a number of boratriazaroles by treating a 46 hydrazonamide with substituted boronic acids. ${ }^{29,30}$ In 2015, 47 Pitterna and co-workers investigated 3-pyridyl-containing dis48 ubstituted boratriazaroles and found that the heterocycles 49 were stable in slightly basic solution that were in part attributed 50 to steric bulk on the boronic acid substituent. ${ }^{31}$ Kinjo and 51 co-workers demonstrated the synthesis of new B-M and B-E boratriazarole complexes $(\mathrm{M}=$ metal, $\mathrm{E}=\mathrm{C}$-based electro- 52 phile) derived from B-lithiated triazaboryl anions. ${ }^{32,33}$ Our lab 53 explored new boratriazarole-containing biaryl motifs derived 54 from bromoacyl MIDA boronate scaffolds. ${ }^{34}$ The resulting bis- 55 heteroaryl products exhibited excellent thermal stability and 56 formed intermolecular hydrogen bonds in the solid state that are 57 not possible with the $\mathrm{C}=\mathrm{C}$ analogues. Despite the current 58 interest in the synthesis and application of these heterocycles, 59 no study has compared the physical properties of boratriazaroles 60 to their carbon-based analogues. Herein, we report the synthesis 61 and photophysical and electronic properties of boratriazaroles 62 and their analogues. Using a range of experimental and com- 63 putational techniques, we show how structural variations in the 64 five-member heterocycle and the aryl-substitution have a marked 65 effect on the photophysical and electronic properties of 66 boratriazaroles. This work provides fundamental new insight 67 into the properties of boratriazaroles that will aid the design of 68 new molecules and potential functional materials.

\section{RESULTS}

70

A family of trisubstituted azacycles were synthesized to inves- 71 tigate how varying the arrangement of boron, nitrogen, and 72 carbon atoms in the central five-member heterocycle affects 73 photophysical and electronic properties. The compounds of 74 interest are trisubstituted boratriazarole 1 , triazole 2, pyrazole 3, 75 and imidazoles $\mathbf{4}$ and $\mathbf{5}$ (Figure 1). Boratriazarole $\mathbf{1}$ is the par- 76 ent compound of interest. Triazole $\mathbf{2}$ is the analogue of $\mathbf{1}$ where 77

Special Issue: Heterocycles

Received: June 29, 2016 


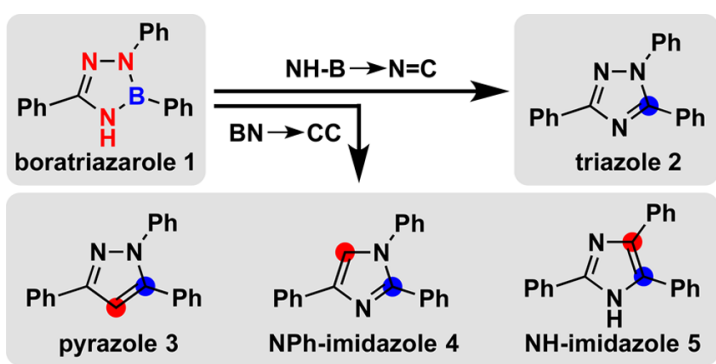

Figure 1. Analogues produced by $\mathrm{NH}-\mathrm{B}$ to $\mathrm{N}=\mathrm{C}$ and $\mathrm{BN}$ to $\mathrm{CC}$ swapping of boratriazarole 1 .

$78 \mathrm{NH}-\mathrm{B}$ is substituted by $\mathrm{N}=\mathrm{C}$. Three other analogues, pyrazole $79 \mathbf{3}$ and imidazoles $\mathbf{4}$ and 5, are variants of $\mathbf{2}$ wherein each 80 nitrogen is systematically replaced with carbon (Figure 1).

81 Boratriazarole $\mathbf{1}$ was prepared from the hydrazone derived 82 from benzaldehyde and phenyl hydrazine (Scheme 1, step a). 83 The hydrazone was chlorinated using in situ-generated 84 N-chlorosuccinimide dimethyl sulfide complex, and the chloride 85 was then displaced by ammonia to afford the hydrazonamide 86 (steps b and c). After refluxing the hydrazonamide with phenyl 87 boronic acid, the crude product was purified by a short silica gel 88 column followed by recrystallization in a diethyl ether/hexanes 89 mixture to furnish $\mathbf{1}$ in $50 \%$ yield (step d). The four analogues 90 of 1 were prepared from commercially available starting mate91 rials following literature procedures (2-5, Scheme 1). Briefly, 92 the hydrazonoyl chloride precursor for $\mathbf{1}$ was also treated with 93 benzylamine, and the resulting hydrazonamide was oxidized to 94 furnish triazole 2 (steps e and f). ${ }^{44}$ Pyrazole 3 was prepared in 95 one step by treating chalcone and phenylhydrazine with 96 molecular iodine (step g). ${ }^{45} \mathrm{NPh}$-imidazole 4 was prepared 97 by a copper-mediated coupling of the corresponding amidine 98 with phenylacetylene $\left(\right.$ step h). ${ }^{46} \mathrm{NH}$-imidazole 5 was 99 synthesized by the acid-mediated condensation of benzil, 100 benzaldehyde, and ammonia (step i). ${ }^{47}$

101 Optical absorption experiments were conducted in chloro102 form solution at room temperature to determine the photo103 physical properties of $\mathbf{1 - 5}$. The absorption spectrum of each 104 compound is generally broad and featureless. Boratriazarole $\mathbf{1}$ 105 has an absorption maximum $\left(\lambda_{\max }\right)$ at $283 \mathrm{~nm}$ and a molar 106 absorption coefficient of $2.12 \times 10^{4} \mathrm{M}^{-1} \mathrm{~cm}^{-1}$ (Figure 2, Table 1)

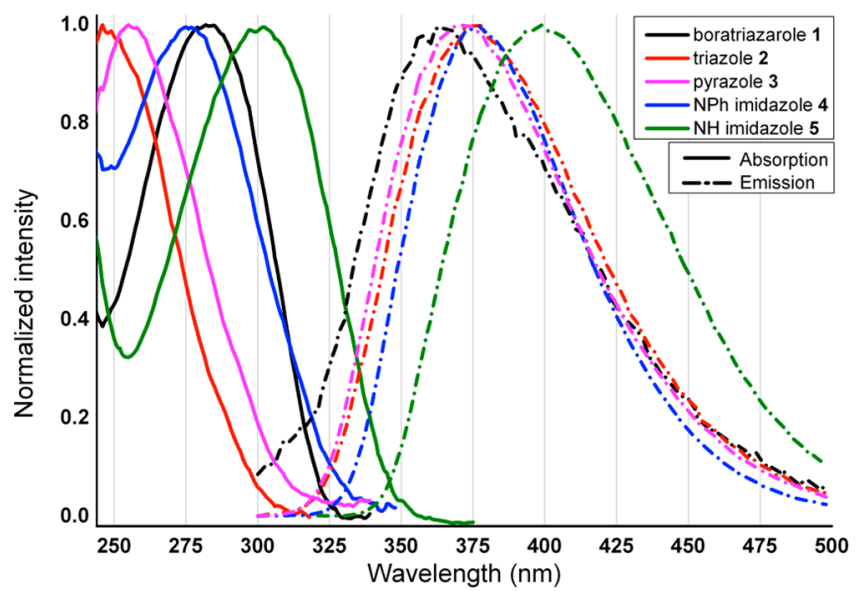

Figure 2. Normalized absorption and fluorescence emission spectra in chloroform for analogues 1-5. An excitation wavelength of $270 \mathrm{~nm}$ was used for $1-4$, and $300 \mathrm{~nm}$ was used for 5 .

In comparison to its analogues, the absorption spectrum of $\mathbf{1}$ is 107 increasingly more red-shifted relative to NPh-imidazole 4, 108 pyrazole 3, and triazole 2 and blue-shifted relative to NH- 109 imidazole $\mathbf{5}$. The red shift of $\mathbf{5}$ may be attributed to an increase 110 in phenyl-phenyl conjugation through the $\mathrm{C}=\mathrm{C}$ double bond 111 in the imidazole. Moreover, the absorption maximum of $\mathbf{1}$ is 112 most similar to that of NPh-imidazole 4, differing by only $6 \mathrm{~nm} .113$ Overall, the absorption maximum and the molar absorption 114 coefficient of boratriazarole 1 fall within the range of its carbon- 115 based analogues.

116

Using 2,5-diphenyloxazole (PPO) in cyclohexane as a stan- 117 dard $\left(\Phi_{\mathrm{F}}=0.84\right){ }^{48,49}$ we determined the relative fluorescence 118 quantum yield of compounds $\mathbf{1 - 5}$ in chloroform. We found 119 that $\mathrm{NH}$ imidazole $\mathbf{5}$ has the highest quantum yield of the series 120 at $0.27,50$ whereas boratriazarole $\mathbf{1}$ has the lowest quantum 121 yield of 0.01 (Table 1, $\Phi_{\mathrm{F}(\mathrm{rel})}$ ). ${ }^{25}$ The NH-B to $\mathrm{N}=\mathrm{C}$ swapped 122 triazole 2 has a quantum yield of 0.03 and is most similar to $\mathbf{1} .123$ Although triazole 2 has a low quantum yield, it exhibits the 124 largest Stokes shift of $13706 \mathrm{~cm}^{-1}$, whereas boratriazarole 1 has 125 the smallest Stokes shift of $7863 \mathrm{~cm}^{-1}$ (Table 1). 126

To gain insight into the electronic properties of compounds 127 1-5, we performed density functional theory (DFT) calcu- 128 lations using Gaussian 09. ${ }^{51}$ Time-dependent density functional 129

Scheme 1. Analogue syntheses ${ }^{a}$

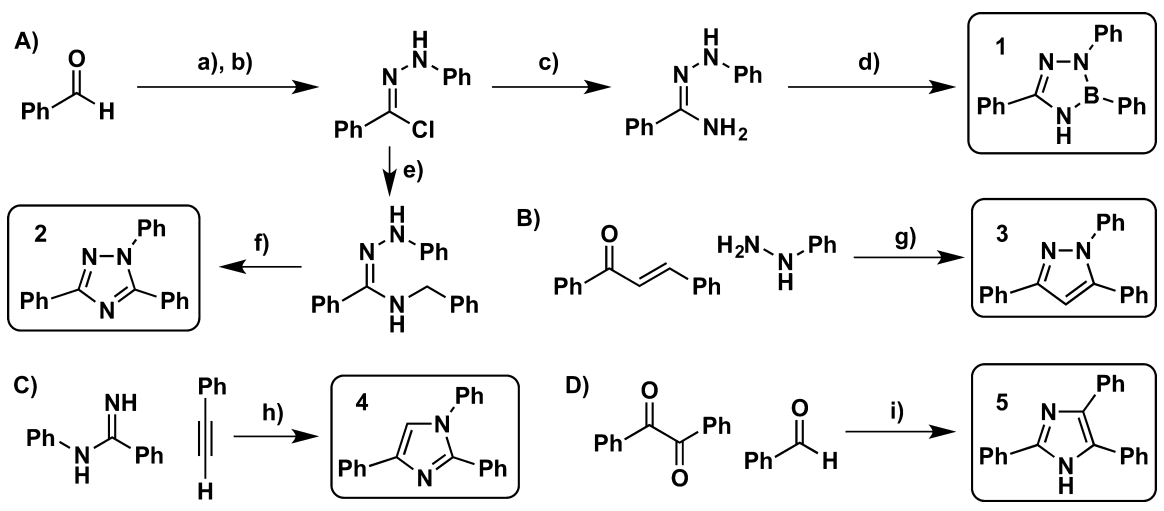

${ }^{a}$ Syntheses of (A) boratriazarole 1 and triazole 2 from a common precursor, (B) pyrazole 3, (C) NPh-imidazole 4, and (D) NH-imidazole 5. Conditions: (a) $\mathrm{PhNHNH}_{2}, \mathrm{EtOH}, 80^{\circ} \mathrm{C}$ (52\%); (b) N-chlorosuccinimide (NCS), $\mathrm{SMe}_{2}, \mathrm{DCM}, 0$ to $-78^{\circ} \mathrm{C}$ to rt $(64 \%)$; (c) $7 \mathrm{~N} \mathrm{NH} 3$ in $\mathrm{MeOH}^{\circ}$ rt (99\%); (d) $\mathrm{PhB}(\mathrm{OH})_{2}$, toluene, $100{ }^{\circ} \mathrm{C}(50 \%) ;(\mathrm{e}) \mathrm{BnNH}_{2}$, TEA, MeCN (72\%); (f) Dess-Martin periodinane (DMP), DCM, rt (62\%); $\left.{ }^{44} \mathrm{~g}\right) \mathrm{I}_{2}$, $100{ }^{\circ} \mathrm{C}(63 \%) ;{ }^{45}(\mathrm{~h}) \mathrm{CuCl}_{2} \cdot \mathrm{H}_{2} \mathrm{O}$, pyridine, $\mathrm{Na}_{2} \mathrm{CO}_{3}, \mathrm{O}_{2}, \mathrm{DCE}, 70{ }^{\circ} \mathrm{C}(30 \%) ;{ }^{46}$ (i) $\mathrm{NH}_{4} \mathrm{OAc}, \mathrm{AcOH}, 75{ }^{\circ} \mathrm{C}(30 \%) .{ }^{47}$ 
Table 1. Summary of Photophysical and Computational Data for Analogues 1-5 Ordered by Increasing $\lambda_{\max (\mathrm{abs})}$

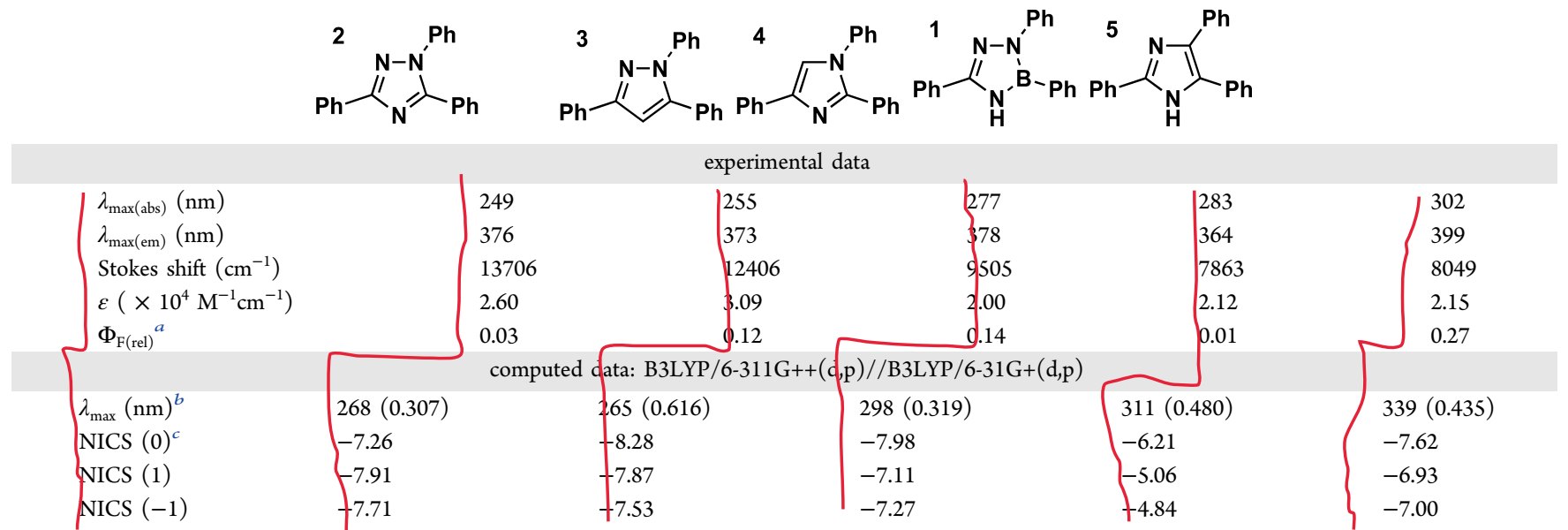

${ }^{a}$ Quantum yield calculated relative to PPO standard in cyclohexane $\Phi_{\mathrm{F}}=0.84 .{ }^{b} \mathrm{TDDFT}: \lambda_{\max }$ corresponding to major oscillator; oscillator strength in parentheses. ${ }^{c} \mathrm{GIAO}$ method.

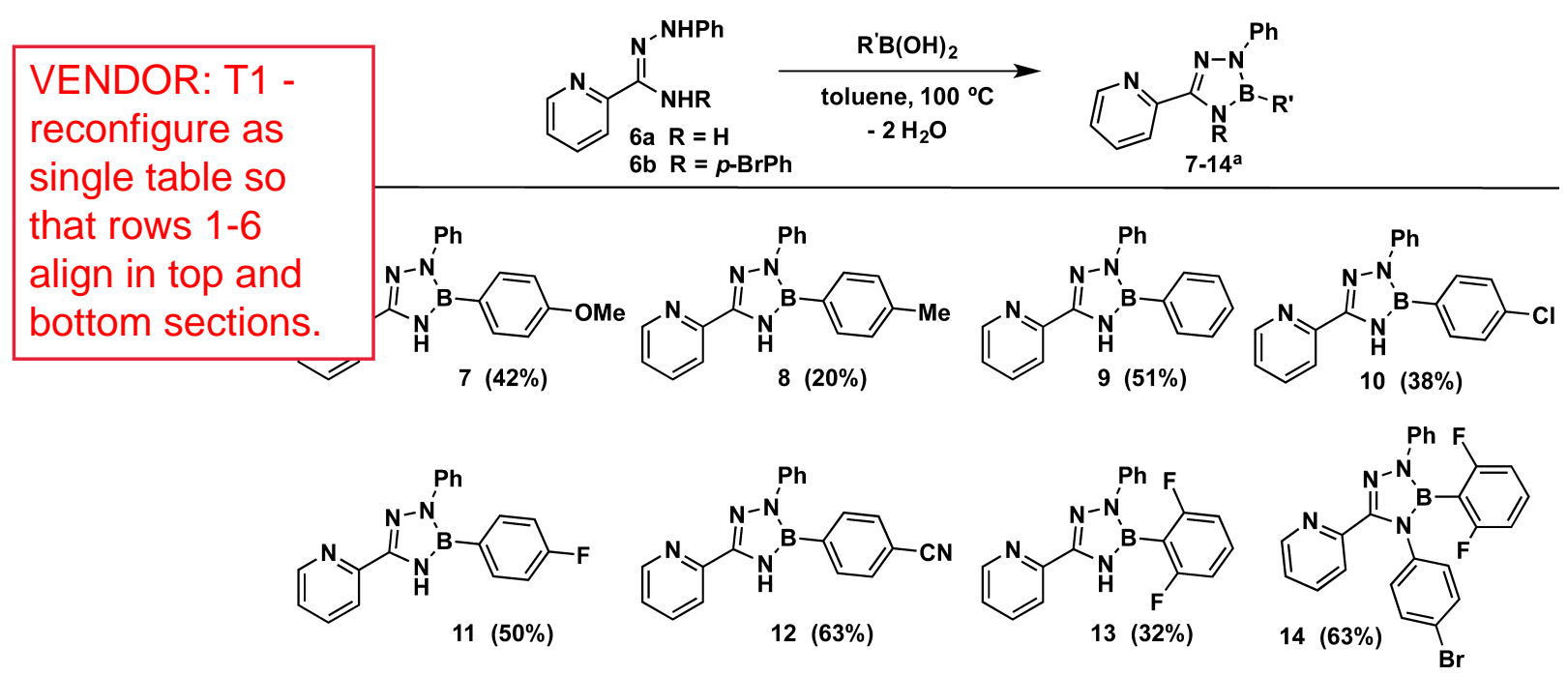

Figure 3. Boratriazarole synthesis using 2-pyridyl-substituted hydrazonamides. ${ }^{a}$ Recrystallization yields after eluting through a plug of silica gel.

130 theory (TDDFT) calculations were carried out using B3LYP/6$131311 \mathrm{G}++(\mathrm{d}, \mathrm{p})$ on geometries optimized using B3LYP/6-31G $132+(\mathrm{d}, \mathrm{p})$. Stationary points were analyzed using frequency calcu133 lations at $298 \mathrm{~K}$. The calculations slightly overestimated the 134 absorption $\lambda_{\max }$ (corresponding to the transition with the highest 135 oscillator strength) but were consistent with the overall exper136 imental trend (Table 1, $\lambda_{\max }$ computed). We also performed 137 nucleus-independent chemical shift (NICS) calculations at the 138 centroid (0), and one angstrom above and below the plane of 139 the 5-member ring (NICS (1) and NICS (-1), respectively) to 140 assess aromaticity. ${ }^{52}$ A more negative NICS value implies higher 141 aromatic character when comparing rings of the same size. 142 On the basis of the obtained values, boratriazarole 1 is in fact 143 aromatic with a NICS (0) value of -6.21 , but to a lesser extent 144 compared to $\mathbf{2}-\mathbf{5}$ as indicated by their more negative NICS 145 values ranging from -8.28 to -7.26 (Table 1 , NICS).

146 Having characterized boratriazarole 1 relative to analogues 147 2-5, we next sought to understand how the B-aryl substituents 148 of boratriazaroles influence the photophysical and electronic 149 properties. In our pursuit to synthesize boratriazaroles from 150 various hydrazonamide precursors, we found the preparation 151 of 2-pyridyl hydrazonamides 6 to be the most efficient and 152 scalable. The attempted synthesis of various other hydrazonoyl chlorides using the chlorination procedures led to no reaction 153 due to insolubility in the case of 2-naphthyl substitution, or 154 mixtures of undesired products with 3- and 4-pyridyl sub- 155 stitution. We thus used $\mathbf{6}$ to prepare a small series of 2-pyridyl- 156 substituted boratriazaroles with various aryl boronic acids. 157 The appropriate B-aryl substituents were selected to investigate 158 how electronic properties (7-12) and steric strain (2,6-difluoro- 159 13 and -14) influences structural and optoelectronic properties 160 (Figure 3).

Recrystallization of four 2-pyridyl-substituted boratriazaroles 162 yielded crystals suitable for X-ray analysis. Electron-donating $p$ - 163 OMe-7 and withdrawing $p$-CN-12, as well as more sterically 164 encumbered 2,6-difluorophenyl boronic acid-derived tri- and 165 tetrasubstituted boratriazaroles 13 and $\mathbf{1 4}$ were analyzed. A dif- 166 ference in the solid-state arrangement is observed for difluoro- 167 trisubstituted boratriazarole 13, which engages in two inter- 168 molecular hydrogen bonds with the pyridine nitrogen and 169 the $\mathrm{NH}$ of the central ring in a dimeric fashion. Interestingly, 170 crystallization of $p$-CN-12 led to crystals containing a 2:1 mix- 171 ture of product to hydrazonamide starting material. In the 172 crystal, one molecule of $\mathbf{1 2}$ is hydrogen bonded to the hydra- 173 zonamide with the same two atoms as that of 13 , whereas 174 the other molecule of $\mathbf{1 2}$ is not participating in any hydrogen 175 


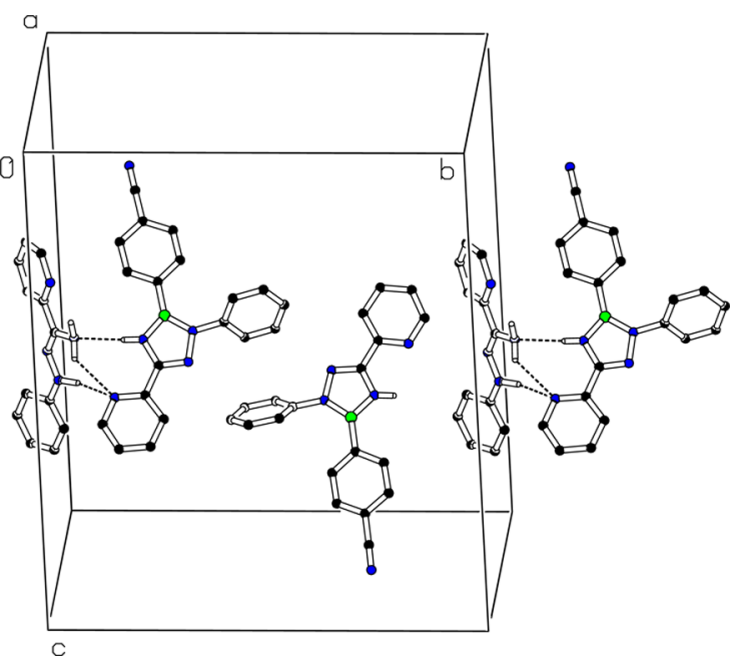

Figure 4. Unit cell of the crystal displaying two molecules of 12 and one molecule of hydrazonamide $\mathbf{6 a}$.

176 bonds (Figure 4).$^{53}$ Compounds 7 and $\mathbf{1 4}$ do not participate in 177 hydrogen bonding in the solid state. Table 2 lists pertinent 178 structural bond lengths and dihedral angles (see Supporting 179 Information for additional X-ray crystallographic data).

180 Keeping the 2-pyridyl and $N$-phenyl groups on the 181 boratriazarole constant allowed us to assess the role of the 182 B-aryl substituent on photophysical properties. To this end, we 183 recorded the optical absorption and fluorescence spectra for 184 the six para-substituted boratriazaroles $(\mathbf{7 - 1 2})$ as well as the 185 difluorophenyl boronic acid derived tri- and tetrasubstituted 186 boratriazaroles (13 and 14). The solution absorption maxima 187 of compounds 7-13 fall between 301 and $308 \mathrm{~nm}$, which we 188 assign to the $0-0$ vibronic transition (Figure 5, Table $3, \lambda_{\max (\mathrm{abs})}$ ). 189 In contrast, tetrasubstituted $\mathbf{1 4}$ has an absorption maximum at $190240 \mathrm{~nm}$ and a lower intensity band at $272 \mathrm{~nm}$. Given the similar 191 energy of this longer wavelength transition to the $0-0$ vibronic 192 band of compounds 7-13, we tentatively assign the feature 193 at $272 \mathrm{~nm}$ to the $0-0$ vibronic transition. The higher energy 194 feature at $240 \mathrm{~nm}$ thus presumably corresponds to a higher 195 energy vibronic transition common to each molecule in the 196 series. All of the molecules have molar absorption coefficients 197 ranging from $1.51 \times 10^{4}$ to $2.33 \times 10^{4} \mathrm{M}^{-1} \mathrm{~cm}^{-1}$ with 14 198 having the lowest (calculated at $272 \mathrm{~nm}$ ) and $p-\mathrm{CN}-12$ having 199 the highest value (Table 3, $\varepsilon$ ). The fluorescence emission $\lambda_{\max }$ 200 of all but one of the compounds occurs within a small range

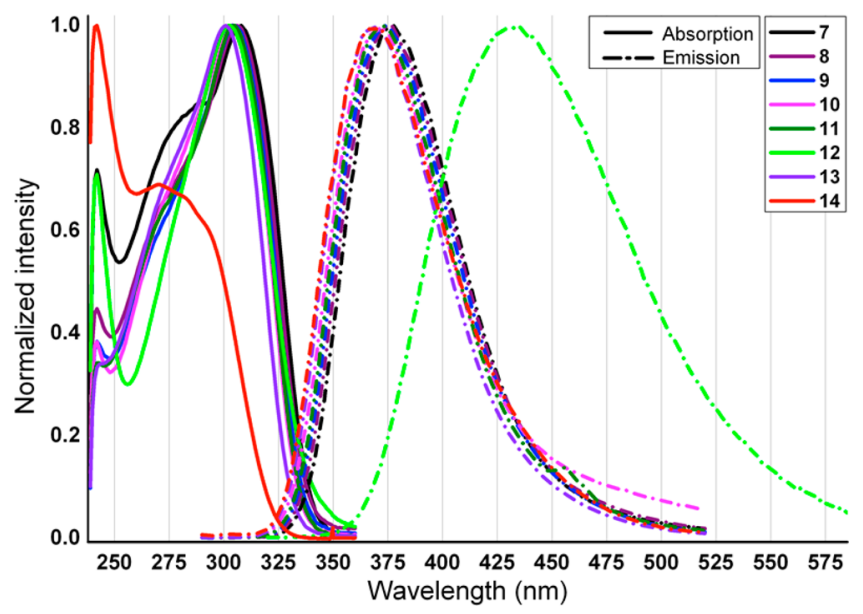

Figure 5. Normalized absorption and fluorescence emission spectra in chloroform for boratriazaroles 7-14. An excitation wavelength of 270 $\mathrm{nm}$ was used for 7-11, 13, and 14, and $300 \mathrm{~nm}$ was used for 10 .

from 368 to $377 \mathrm{~nm}$ (Figure 5, Table 3, $\lambda_{\max (\mathrm{em})}$ ). The emission 201 maximum of $p-\mathrm{CN}-12$ occurs at $435 \mathrm{~nm}$ and exhibits the largest 202 Stokes shift of $10015 \mathrm{~cm}^{-1}$. Tetrasubstituted 14 also has a large 203 Stokes shift of $9664 \mathrm{~cm}^{-1}$. Furthermore, we obtained the quan- 204 tum yields for all compounds relative to PPO and found that 205 switching the hydrazonamide-derived phenyl group of $\mathbf{1}$ to 206 (2-pyridyl)-9 led to a drastic increase in the quantum yield 207 of the boratriazarole from 0.01 to 0.47 (Table 3, $\left.\Phi_{\mathrm{F}(\mathrm{rel})}\right)$. The 208 quantum yields of the various trisubstituted compounds do not 209 follow a trend based on the electronic properties of the B-aryl ring 210 $\left(\Phi_{\mathrm{F}}=0.32-0.52\right)$. Tetrasubstituted boratriazarole 14 has a much 211 lower quantum yield of 0.13 .

212

Compounds with large Stokes shifts often exhibit solvato- 213 chromic behavior. ${ }^{54-56}$ Because $p$-CN-12 displayed a significantly 214 larger Stokes shift relative to of the other compounds in 215 the series, we investigated the solvatochromic behavior of this 216 compound by recording the absorption and emission spectra of 217 12 in solvents with varying polarities. The absorption maxi- 218 mum of 12 varies within a small range of 297-303 nm when 219 recorded in these solvents (Table 4). The emission maximum 220 of 12, however, is substantially red-shifted as the polarity 221 of the solvent increases. In diethyl ether, the emission maxi- 222 mum appears at $412 \mathrm{~nm}$, corresponding to a Stokes shift of 223 $8950 \mathrm{~cm}^{-1}$, and in the more polar acetonitrile, the emission 224 maximum appears at $448 \mathrm{~nm}$ with a correspondingly larger 225

Table 2. Selected X-ray Crystallographic Data for 7 and $12-14^{a}$

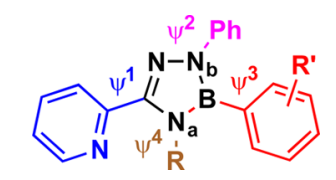

\begin{tabular}{|c|c|c|c|c|}
\hline & 7 & $12^{b}$ & $13^{b}$ & 14 \\
\hline & $\mathrm{R}=\mathrm{H}, \mathrm{R}^{\prime}=p-\mathrm{OMe}$ & $\mathrm{R}=\mathrm{H}, \mathrm{R}^{\prime}=p-\mathrm{CN}$ & $\mathrm{R}=\mathrm{H}, \mathrm{R}^{\prime}=2,6-\mathrm{F}_{2}$ & $\mathrm{R}=p-\mathrm{BrPh}, \mathrm{R}^{\prime}=2,6-\mathrm{F}_{2}$ \\
\hline $\mathrm{B}-\mathrm{N}_{\mathrm{a}}(\AA)$ & $1.4300(17)$ & $1.427(2), 1.428(2)$ & $1.419(2), 1.416(2)$ & $1.438(3)$ \\
\hline $\mathrm{B}-\mathrm{N}_{\mathrm{b}}(\AA)$ & $1.4312(17)$ & $1.432(2), 1.430(2)$ & $1.427(2), 1.434(2)$ & $1.414(3)$ \\
\hline$\psi^{1}(\operatorname{deg})$ & $2.31(9)$ & $6.77(11), 7.03(11)$ & $10.10(9), 13.02(9)$ & $32.05(13)$ \\
\hline$\psi^{2}(\mathrm{deg})$ & $72.03(4)$ & $54.73(5), 52.66(5)$ & $10.63(9), 13.66(9)$ & $24.15(8)$ \\
\hline$\psi^{3}(\mathrm{deg})$ & $11.0(3)$ & $11.20(10), 6.22(10)$ & $76.62(7), 51.58(7)$ & $56.43(9)$ \\
\hline$\psi^{4}(\mathrm{deg})$ & & & & $63.59(10)$ \\
\hline
\end{tabular}

$a \psi=$ dihedral angle between the two aryl rings. ${ }^{b}$ Two values for 12 and 13 correspond to two molecules in the unit cell. 
Table 3. Summary of Photophysical and Computational Data for Boratriazaroles 7-14

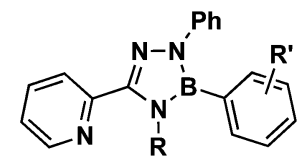

VENDOR: Please move "experimental data" heading to be similar to "computed data" heading below.

\begin{tabular}{|c|c|c|c|c|c|c|c|c|}
\hline & \multicolumn{7}{|c|}{$\mathrm{R}=\mathrm{H}$} & \multirow{2}{*}{$\frac{\mathrm{R}=p-\mathrm{BrPh}}{14}$} \\
\hline & 7 & 8 & 9 & 10 & 11 & 12 & 13 & \\
\hline & $\mathrm{R}^{\prime}=p \mathrm{QMe}$ & $\mathrm{R}^{\prime}=p-\mathrm{Me}$ & $\mathrm{R}^{\prime}=p-\mathrm{H}$ & $\mathrm{R}^{\prime}=p-\mathrm{Cl}$ & $\mathrm{R}^{\prime}=p-\mathrm{F}$ & $\mathrm{R}^{\prime}=p-\mathrm{CN}$ & $\mathrm{R}^{\prime}=2,6-\mathrm{F} 2$ & $\mathrm{R}^{\prime}=2,6-\mathrm{F} 2$ \\
\hline$\lambda_{\max (\mathrm{abs})}(\mathrm{nm})$ & 308 & 306 & 305 & 303 & 305 & 303 & 301 & 272 \\
\hline$\lambda_{\max (\mathrm{em})}(\mathrm{nm})$ & 377 & 375 & 374 & 372 & 372 & 435 & 368 & 369 \\
\hline Stokes shift $\left(\mathrm{cm}^{-1}\right)^{a}$ & 5942 & 6013 & 6049 & 6122 & 5905 & 10015 & 6049 & 9664 \\
\hline$\varepsilon\left(\times 10^{4} \mathrm{M}^{-1} \mathrm{~cm}^{-1}\right)$ & 1.99 & 2.06 & 1.77 & 2.21 & 2.05 & 2.33 & 2.11 & 1.51 \\
\hline$\Phi_{\mathrm{F}(\mathrm{rel})}^{b}$ & 0.52 & 0.44 & 0.47 & 0.32 & 0.52 & 0.32 & 0.51 & 0.13 \\
\hline
\end{tabular}

\begin{tabular}{|c|c|c|c|c|c|c|}
\hline$\lambda_{\max }(\mathrm{nm})^{c}$ & $335(0.334)$ & $329(0.369)$ & $327(0.377)$ & $324(0.391)$ & $324(0.377)$ & $318(0.377)$ \\
\hline $\operatorname{NICS}(0)^{d}$ & -6.52 & -6.59 & -6.64 & -6.69 & -6.69 & -6.78 \\
\hline $\operatorname{NICS}(1)$ & -5.25 & -5.26 & -5.37 & -5.45 & -5.36 & -5.46 \\
\hline $\operatorname{NICS}(-1)$ & -5.08 & -5.15 & -5.27 & -5.20 & -5.22 & -5.30 \\
\hline
\end{tabular}

VENDOR: Add colon, then run-in text into a single line, similar to ${ }^{a}$ The Stokes shift is quoted as the difference between the $0-0$ vibronic band of the solution absorption spectrun format in Table 1
maximum. ${ }^{b}$ Quantum yield calculated relative to PPO standard in cyclohexane $\left(\Phi_{\mathrm{F}}=0.84\right)$. ${ }^{c}$ TDDFT: $\lambda_{\max }$ corresponding to major osclllator; maximum. ${ }^{b}$ Quantum yield calculated relative to $\mathrm{PPC}$
oscillator strength in parentheses. ${ }^{d}$ GIAO method.

Table 4. Absorption and Emission Maxima and Stokes Shift for 12 in Different Solvents

\begin{tabular}{llllll}
\multicolumn{1}{c}{ solvent } & $\mathrm{Et}_{2} \mathrm{O}$ & $\mathrm{THF}$ & $\mathrm{EtOAc}$ & $\mathrm{CHCl}_{3}$ & $\mathrm{MeCN}$ \\
$\lambda_{\max (\mathrm{abs})}(\mathrm{nm})$ & 301 & 302 & 300 & 303 & 295 \\
$\lambda_{\max (\mathrm{em})}(\mathrm{nm})$ & 412 & 424 & 424 & 435 & 448 \\
Stokes shift $\left(\mathrm{cm}^{-1}\right)^{a}$ & 8950 & 9528 & 9748 & 10014 & 11576
\end{tabular}

${ }^{a}$ The Stokes shift is quoted as the difference between the $0-0$ vibronic band of the solution absorption spectrum and the solution emission maximum.

226 Stokes shift of $11576 \mathrm{~cm}^{-1}$. Using methanol and DMSO as 227 solvent led to significant emission quenching compared to that 228 of the other solvents, possibly due to sample decomposition. 229 Nevertheless, a Stokes shift of similar magnitude to that of 230 acetonitrile was observed for each of these polar solvents (see 231 Supporting Information) and is consistent with positive sol232 vatochromism.

233 We next conducted computational studies on the substituted 234 boratriazaroles to further understand their electronic properties. 235 As with analogues $\mathbf{1 - 5}$, the calculated absorbance maxima were 236 slightly overestimated but consistent with the trend of the 237 experimental values for $\mathbf{7 - 1 4}$ (Table $3, \lambda_{\max }$ computed). NICS 238 calculations revealed that the central boratriazarole ring is 239 relatively more aromatic with the 2-pyridyl substitution com240 pared to 1 . Consistent with the data from the $\mathrm{B}-\mathrm{N}$ bond 241 lengths derived from the X-ray crystallographic data 242 (vide infra), NICS calculations also show a trend of increased 243 aromaticity with more electron-withdrawing substituents. To 244 gain insight into the substantial Stokes shift with $p$-CN-12, the $245 \mathrm{HOMO}$ and LUMO orbitals from the TDDFT calculations 246 were visualized. In general, $p$-OMe, $p-\mathrm{Me}, p-\mathrm{H}, p-\mathrm{Cl}, p-\mathrm{F}$, 247 and 2,6-difluoro-substituted boratriazaroles have very similar $248 \mathrm{HOMO}$ and LUMO orbitals (Figure 6, only OMe and $\mathrm{Cl}$ shown, 249 see Supporting Information for more detail). The HOMO is 250 delocalized among the four aryl rings, and the LUMO pre251 dominates on the pyridyl ring with no contribution from the
B-aryl substituent. The introduction of the $p$-CN substitution 252 drastically alters the electronic distribution in the LUMO 253 orbital, which predominates on the B-aryl substituent. With 254 the additional $\mathrm{N}$-aryl ring in 14, there is less delocalization in 255 the HOMO orbital and a large contribution of the new N-aryl 256 ring to the LUMO orbital. The transitions corresponding to the 257 highest oscillator strengths are from the HOMO to the LUMO 258 for all compounds except 12. Although the HOMO to LUMO 259 transition does contribute to the spectrum of $12(f=0.187), 260$ the transition with the highest oscillator strength is HOMO to 261 LUMO +1 in nature $(f=0.377)$. The electronic distribution in 262 the LUMO+1 of 12 resembles that of the LUMOs of all of the 263 other compounds.

\section{DISCUSSION}

265

On the basis of our study, the boratriazaroles are less aromatic 266 compared to that of the carbon-based analogues. This property 267 is elucidated by the NICS calculations, whereby the NICS 268 values for $\mathbf{1}$ are less negative than those for $\mathbf{2} \mathbf{- 5}$. We conclude 269 that the boratriazaroles do not exist as the formally zwitterionic 270 $\mathrm{RHN}^{+}=\mathrm{B}^{-} \mathrm{NPh}$ species; rather, the $\mathrm{NH}$ lone pair in $\mathbf{1}$ is more 271 localized on nitrogen and partially donating into the boron 272 p-orbital. The overall aromaticity is further supported by the 273 X-ray crystallographic data of 7 and 12-14, which show that 274 the central boratriazarole rings are essentially planar with 275 root-mean-square deviations in the range of 0.004-0.006 $\AA .276$ The trend of decreased aromaticity in the boratriazaroles is 277 consistent with that in other studies of BN heterocycles. ${ }^{26,27,57} 278$

We have investigated changes in the boron-nitrogen bond 279 lengths as well as changes in the dihedral angles between the 280 central boratriazarole ring and its flanking aryl groups (Table 2) 281 in the X-ray crystallographic data of the 2-pyridyl-boratriazarole 282 analogues $p$-OMe-7, p-CN-12, 2,6-difluoro-13, and tetrasub- 283 stituted-14. Because $\mathrm{N}_{\mathrm{b}}$ is bound to a phenyl group, which will 284 delocalize the nitrogen lone pair, the resulting $\mathrm{N}_{\mathrm{b}}-\mathrm{B}$ bond 285 lengths for 7, 12, and $\mathbf{1 3}$ are longer than $\mathrm{N}_{\mathrm{a}}-\mathrm{B}$. There is more 286 donation of the $\mathrm{N}_{\mathrm{a}} \mathrm{H}$ lone pair into the p-orbital of boron. As 287 


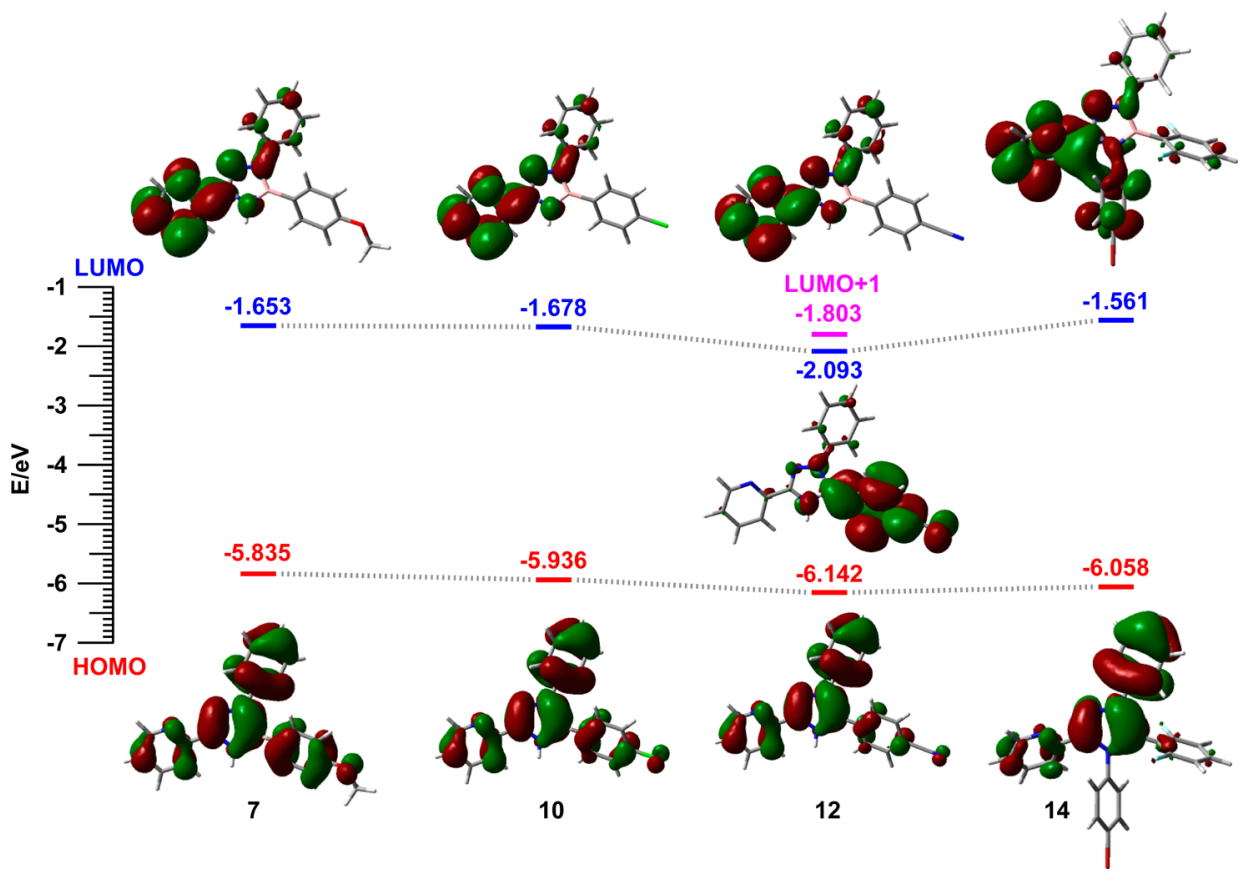

Figure 6. Computed HOMO and LUMO orbitals of p-OMe-7, Cl-10, and CN-12, and 14.

288 the electron-withdrawing nature of the B-aryl substituent 289 increases, the bond length between the boron and both nitro290 gen atoms decreases. By swapping the $\mathrm{NH}$ with $\mathrm{N}$-aryl (as in 291 14), the $N_{b}-B$ bond becomes shorter than $N_{a}-B$, presumably 292 due to steric repulsion between the $\mathrm{N}_{\mathrm{a}}$-aryl group with the 293 pyridyl and B-aryl substituents. For each compound, all B-N 294 bond lengths are longer than a B-N double bond $(\sim 1.41 \AA)$ 295 implying electron delocalization in the aromatic system. ${ }^{58}$

296 Steric repulsion was also assessed by the dihedral angles 297 between the central boratriazarole ring and its flanking aryl 298 rings. For 7 and 12, the $\mathrm{N}_{\mathrm{b}}$-phenyl ring $\left(\psi^{2}\right)$ is twisted the most 299 out of plane at $72^{\circ}$ and $\sim 53^{\circ}$, respectively, whereas the pyridyl $300\left(\psi^{1}<7^{\circ}\right)$ and B-aryl $\left(\psi^{3}<12^{\circ}\right)$ are nearly in plane with the 301 central ring. In contrast, bulkier difluoro-13 has the B-aryl 302 group twisted approximately $64^{\circ}$ out of plane, whereas the 303 pyridyl and phenyl groups are more in plane $\left(\psi^{1,2}<14^{\circ}\right)$. Once 304 an aryl substituent is introduced on $\mathrm{N}_{\mathrm{a}}$ as with $\mathbf{1 4}$, all dihedral 305 angles increase, thus decreasing electronic communication 306 among the $\pi$-systems and affecting the absorption properties.

307 With the exception of $\mathrm{NH}$-imidazole 5, the boratriazaroles 308 contain a hydrogen bond donor $\mathrm{NH}$ that is absent from the 309 other analogues. In our previous studies of boratriazaroles, we 310 observed that the $\mathrm{NH}$ functionality is capable of engaging in 311 intermolecular hydrogen bonding interactions in the solid 312 state. $^{34}$ Hydrogen bonding capabilities were also further 313 elucidated in the solid state of the (2-pyridyl)boratriazaroles. 314 Only difluoro-13 was capable of participating in intermolecular 315 hydrogen bonding in a dimeric fashion. The other observed 316 case of hydrogen bonding was with $p-\mathrm{CN}-12$, which was unable 317 to pack in a dimeric fashion but cocrystallized with the hydra318 zonamide starting material (vide supra, Figure 4). Because the 319 dihedral angle $\psi^{3}$ of $\mathbf{1 3}$ is high $\left(>50^{\circ}\right)$ due to the difluoro 320 substitution, the compound is able to accommodate hydrogen321 bond donor/acceptor interactions with a second molecule of 32213 with minimal steric penalty. On the other hand, $\psi^{3}$ of 12 is 323 much lower $\left(<12^{\circ}\right)$ with increased electronic communication 324 between the two aryl rings, which renders dimerization in the 325 solid state sterically inaccessible. The cocrystallized hydrazona- mide can be oriented to minimize steric repulsion and favorably 326 hydrogen bond with the boratriazarole (see Supporting 327 Information for X-ray crystallographic data). The unusual 328 cocrystallization of the product with residual starting material 329 may speak to the high propensity of these pyridyl boratria- 330 zaroles to participate in hydrogen bonding, which is a desirable 331 property for applications in medicinal chemistry.

332

Relative to the carbon-based analogues (2-5), boratriazarole 333 1 generally has similar absorption and emission spectra, but has 334 a very low quantum yield. The quantum yield, however, can be 335 increased with the inclusion of a pyridyl group in the molecule. 336 A number of conclusions can be drawn from the photophysical 337 data as well as the TDDFT calculations and molecular orbital 338 diagrams for the HOMO and LUMO of 7-14. With trisub- 339 stituted boratriazaroles $7-\mathbf{1 3}$, the HOMO is delocalized across 340 the entire molecule. With the exception of $p-\mathrm{CN}-12$, the main 341 computed transition contributing to the absorption spectrum is 342 a HOMO to LUMO $\pi-\pi^{*}$ transition with some charge transfer 343 character away from the B-aryl ring onto the pyridyl ring. When 344 donor and acceptor units are connected through a single bond, 345 such charge-transfer behavior is accompanied by a change in 346 geometry to establish a lower-energy twisted intramolecular 347 charge-transfer state (TICT). ${ }^{59}$ This lower energy TICT state 348 is observed in the emission spectrum as a significant Stokes 349 shift. The main computed transition in $\mathbf{1 2}$ also involves similar 350 charge-transfer behavior away from the B-aryl group; however, 351 in this case, the transition occurs from HOMO to LUMO+1. 352 A second lower intensity but significant transition for $\mathbf{1 2}$ is from 353 the HOMO to LUMO, which exhibits a nearly complete charge 354 transfer onto the B-aryl ring (Figure 6). Thus, compound 12355 exhibits a significantly larger Stokes shift than the other com- 356 pounds. This phenomenon is further supported by the positive 357 solvatochromism observed for compound 12, as excited states 358 with strong charge-transfer character are greatly stabilized 359 by polar solvents. Finally, the nearly complete transfer of elec- 360 tron density to the B-aryl ring in the LUMO likely yields a 361 more highly twisted TICT structure than the other compounds, 362 
363 which is reflected in the dramatically decreased quantum yield 364 of emission.

\section{$365-$ CONCLUSIONS}

366 We have synthesized a family of substituted boratriazaroles 367 and have studied their photophysical and structural properties. 368 Three $\mathrm{BN}$ to $\mathrm{CC}$ isosteres were prepared along with one $369 \mathrm{NH}-\mathrm{B}$ to $\mathrm{N}=\mathrm{C}$ substituted analogue. The boratriazaroles are 370 aromatic, but to a lesser extent compared to that of imidazole, 371 triazole, and pyrazole scaffolds. The quantum yield of the 372 model triphenyl-boratriazarole is significantly lower than those 373 of the carbon-based analogues but is shown to significantly 374 improve upon substitution of one phenyl group with a 2-pyridyl 375 group. This observation showcases the potential to tune 376 photophysical properties of boratriazaroles. We subsequently 377 analyzed the electronic and steric influence of the B-aryl ring on 378 the photophysical properties. Although there was not a strong 379 trend between the electronic properties of the B-aryl ring 380 and the quantum yield, the overall aromaticity of the central 381 boratriazarole ring is increased with electron-withdrawing 382 groups. For the most part, the absorption and emission spectra 383 (as well as the HOMO and LUMO levels) are not greatly 384 influenced by the electronic properties of the B-aryl ring. 385 The $p$-CN derivative is the exception to this trend, which has a 386 large bathochromic shift relative to that of the other compounds 387 and displays positive solvatochromic behavior. These data reveal 388 that the boron atom in underexplored boratriazaroles is par389 ticipating in electronic communication in the excited state. 390 Judicious choice of the B-aryl substituents (such as the $p$-CN 391 derivative disclosed here) can be used to tune the photo392 physical properties, adding further understanding to the 393 influence and behavior of boron-containing heterocycles in 394 polyaromatic systems. In conjunction with these findings, the 395 use of computational tools to assess the photophysical pro396 perties of various substituted boratriazaroles is expected to aid 397 in the development of new and improved materials.

\section{EXPERIMENTAL SECTION}

399 2,3,5-Triphenyl-2,3-dihydro-1H-1,2,4,3-triazaborole (1). Ben400 zaldehyde $(2.0 \mathrm{~mL}, 19.6 \mathrm{mmol})$ was dissolved in $95 \%$ ethanol $(20 \mathrm{~mL})$ 401 and heated to $75{ }^{\circ} \mathrm{C}$. Phenylhydrazine $(10.3 \mathrm{~mL}, 104.8 \mathrm{mmol})$ was 402 added dropwise, and the reaction was stirred for $1 \mathrm{~h}$. The reaction was 403 allowed to cool to room temperature with sustained stirring as the 404 product crystallized out of solution. The flask was placed in a freezer 405 for $2 \mathrm{~h}$, and the product was filtered, washed with cold ethanol, and 406 dried under high vacuum to yield $(E)$-1-benzylidene-2-phenyl407 hydrazine $\left(2.01 \mathrm{~g}, 52 \%\right.$, white crystals) ${ }^{60}$ Hydrazonoyl chloride was 408 prepared following literature procedures with consistent spectral 409 data. ${ }^{44,61}$ NCS (12.40 g, $\left.92.9 \mathrm{mmol}\right)$ was dissolved in anhydrous 410 DCM $(128 \mathrm{~mL})$ and cooled to $0{ }^{\circ} \mathrm{C}$. Dimethylsulfide $(13.8 \mathrm{~mL}$, $411188.0 \mathrm{mmol}$ ) was added over $15 \mathrm{~min}$. After stirring for an additional $41215 \mathrm{~min}$, the reaction was cooled to $-78^{\circ} \mathrm{C}$, and the hydrazone $(6.08 \mathrm{~g}$, $41331.0 \mathrm{mmol})$ dissolved in anhydrous DCM $(100 \mathrm{~mL})$ was added 414 dropwise, allowed to stir at that temperature for $1 \mathrm{~h}$, and warmed to 415 room temperature over $3 \mathrm{~h}$. The reaction was quenched with water $416(20 \mathrm{~mL})$. Ethyl acetate was added, and the organic layer was washed 417 with water, brine, saturated sodium sulfite solution, then water and 418 then dried over magnesium sulfate. The solution was filtered and 419 slowly concentrated. The product precipitated or crystallized out of 420 solution during concentration and was filtered to yield pure product. 421 This process could be repeated to yield multiple crops of product $422(Z)$ - $N$-phenylbenzohydrazonoyl chloride (4.58 g, 64\%, tan solid). 423 The hydrazonoyl chloride $(1.50 \mathrm{~g}, 6.50 \mathrm{mmol})$ was dissolved in a mini424 mum amount of methanol, and $7 \mathrm{~N}$ ammonia in methanol $(9.3 \mathrm{~mL}$, $42565.0 \mathrm{mmol}$ ) was added dropwise and stirred for $4 \mathrm{~h}$. The volatiles were removed in vacuo, and the residue was dissolved in ethyl acetate and 426 washed with water and brine and dried over sodium sulfate. The red 427 solution was evaporated, and the product was purified by column 428 chromatography with a gradient of $100 \%$ hexanes to $40 \%$ ethyl acetate 429 in hexanes to yield $(Z)-N^{\prime}$-phenylbenzohydrazonamide as a red oil 430 that crystallized over time; the product turned black and may have 431 decomposed over time (0.766 g, 56\%). Mp: 65-70 ${ }^{\circ} \mathrm{C} .{ }^{1} \mathrm{H}$ NMR 432 $\left(500 \mathrm{MHz}, \mathrm{CDCl}_{3}\right) \delta 7.84-7.72(\mathrm{~m}, 2 \mathrm{H}), 7.44-7.38(\mathrm{~m}, 3 \mathrm{H}), 7.30-433$ $7.22(\mathrm{~m}, 2 \mathrm{H}), 7.12-7.04(\mathrm{~m}, 2 \mathrm{H}), 6.92-6.83(\mathrm{~m}, 1 \mathrm{H}), 4.83$ (br s, 434 $2 \mathrm{H}) .{ }^{13} \mathrm{C} \mathrm{NMR}\left(126 \mathrm{MHz}, \mathrm{CDCl}_{3}\right) \delta 151.3,147.8,134.1,129.9,129.2,435$ $128.7,127.5,125.9,120.3,114.5$. IR (neat) $\tilde{v}\left(\mathrm{~cm}^{-1}\right): 3457,3357,436$ 2928, 1606, 1489, 1384, 824, 750 .

Hydrazonamide $(0.20 \mathrm{~g}, 0.95 \mathrm{mmol})$ and phenyl boronic acid 438 $(0.12 \mathrm{~g}, 0.95 \mathrm{mmol})$ were dissolved in toluene $(3.2 \mathrm{~mL})$. The vessel 439 was sealed and heated with vigorous stirring to $100{ }^{\circ} \mathrm{C}$ for $5 \mathrm{~h}$. The 440 solution was loaded onto a plug of silica gel packed with toluene, and 441 the product was eluted with toluene. The solvent was removed in 442 vacuo and dried thoroughly under high vacuum. The residue was 443 dissolved in a minimum amount of diethyl ether and layered with 444 hexanes to yield pale yellow feather-like crystals of $1(0.144 \mathrm{mg}, 50 \%) .445$ Mp: $136-138{ }^{\circ} \mathrm{C}\left(\mathrm{Et}_{2} \mathrm{O} /\right.$ hexanes $) .{ }^{1} \mathrm{H}$ NMR $\left(500 \mathrm{MHz}, \mathrm{CDCl}_{3}\right) \delta 446$ 7.92-7.84 (m, 2H), 7.63-7.59 (m, 2H), 7.56-7.52 (m, 2H), 7.51 (br 447 s, $1 \mathrm{H}), 7.49-7.45(\mathrm{~m}, 2 \mathrm{H}), 7.44-7.40(\mathrm{~m}, 2 \mathrm{H}), 7.40-7.37(\mathrm{~m}, 2 \mathrm{H}), 448$ 7.35-7.30 (m, 2H), 7.19-7.13 (m, 1H). ${ }^{13} \mathrm{C}$ NMR (126 MHz, 449 $\left.\mathrm{CDCl}_{3}\right) \delta 149.0,143.7,133.6,129.9,129.5,129.4,129.0,128.9,128.3,450$ 125.5, 124.8, 122.1. ${ }^{11} \mathrm{~B}$ NMR (192 $\left.\mathrm{MHz} \mathrm{CDCl}_{3}\right) \delta 28.0$. IR (neat) 451 $\tilde{v}\left(\mathrm{~cm}^{-1}\right): 3264,2927,1600,1498,1349,1069,824,783$. HRMS 452 (DART) $\mathrm{m} / z$ : $[\mathrm{M}+\mathrm{H}]^{+}$calcd for $\mathrm{C}_{19} \mathrm{H}_{17} \mathrm{BN}_{3}$ 298.1516, found 453 298.1517.

1,3,5-Triphenyl-1H-1,2,4-triazole (2). Product 2 was synthesized 455 according to a modified literature procedure ${ }^{44}$ and was consistent with 456 reported spectral data. ${ }^{62}$ Hydrazonoyl chloride $(0.50 \mathrm{~g}, 2.17 \mathrm{mmol}) 457$ was dissolved in DCM $(2.2 \mathrm{~mL})$ followed by the addition of 458 benzylamine $(0.71 \mathrm{~mL}, 6.5 \mathrm{mmol})$ and triethylamine $(0.45 \mathrm{~mL}, 459$ $3.25 \mathrm{mmol}$ ) and stirred for $12 \mathrm{~h}$. The DCM solution was washed with 460 water and then brine and dried over magnesium sulfate. The product 461 was eluted through a plug of silica using a gradient from $100 \%$ hexanes 462 to $50 \%$ ethyl acetate in hexanes to yield (Z)-N-benzyl- $N^{\prime}$-phenyl- 463 benzohydrazonamide as an orange oil $(0.473 \mathrm{~g}, 72 \%)$ that was used 464 immediately in the next step. The hydrazonamide $(0.30 \mathrm{~g}, 1.00 \mathrm{mmol}) 465$ was dissolved in DCM $(10 \mathrm{~mL})$, and Dess-Martin periodinane 466 $(0.64 \mathrm{~g}, 1.50 \mathrm{mmol})$ was added portionwise. The solution was stirred 467 for $5 \mathrm{~h}$, then washed with saturated sodium bicarbonate solution 468 and brine, and dried over magnesium sulfate. The orange/red crude 469 product was purified by column chromatography with a gradient from 470 hexanes to $25 \%$ ethyl acetate in hexanes to yield 2 as an off-white solid 471 (0.183 g, 62\%).

472

1,3,5-Triphenyl-1H-pyrazole (3). Product 3 was synthesized 473 according to a modified literature procedure ${ }^{45}$ and was consistent with 474 reported spectral data. ${ }^{63}$ Phenylhydrazine $(0.71 \mathrm{~mL}, 7.20 \mathrm{mmol})$ and 475 iodine $(1.83 \mathrm{~g}, 7.24 \mathrm{mmol})$ were dissolved in ethanol $(120 \mathrm{~mL})$, and 476 chalcone $(0.50 \mathrm{~g}, 2.40 \mathrm{mmol})$ was added. The reaction was heated to 477 $100{ }^{\circ} \mathrm{C}$ overnight. The ethanol was evaporated, and the product was 478 redissolved in ethyl acetate, washed with saturated sodium sulfite 479 solution and brine, and then dried over sodium sulfate. The product 480 was first purified by column chromatography with a gradient from 481 $100 \%$ hexanes to $10 \%$ ethyl acetate in hexanes and then recrystallized 482 with diethyl ether/hexanes to yield 3 as a light yellow solid (0.448 g, 483 $63 \%)$.

1,2,4-Triphenyl-1 $\mathrm{H}$-imidazole (4). Product 4 was prepared using 485 a literature procedure and was consistent with reported spectral data. ${ }^{46} 486$ Scale: 2.5 mmol. Pale yellow solid $(0.225 \mathrm{~g}, 30 \%)$.

2,4,5-Triphenyl-1H-imidazole (5). Product 5 was prepared using 488 a literature procedure ${ }^{47}$ and was consistent with reported spectral 489 data. ${ }^{64}$ Scale: $5.0 \mathrm{mmol}$. White solid $(0.444 \mathrm{~g}, 30 \%)$. 490

Synthesis of Hydrazonamides (Z)-N'Phenylpicolinohydrazona- 491 mide (6a) and (Z)-N-(4-Bromophenyl)- $N^{\prime}$-phenylpicolinohydrazo- 492 namide (6b). 2-Pyridine carboxaldehyde $(10 \mathrm{~mL}, 105.0 \mathrm{mmol})$ was dis- 493 solved in $95 \%$ ethanol $(100 \mathrm{~mL})$ and heated to $75^{\circ} \mathrm{C}$. Phenylhydrazine 494 $(10.3 \mathrm{~mL}, 105.0 \mathrm{mmol})$ was added dropwise, and the reaction was 495 
496 stirred for $1 \mathrm{~h}$. The reaction was allowed to cool to room temperature 497 with sustained stirring, and the product crystallized out of solution. 498 The flask was placed in a freezer for $2 \mathrm{~h}$, and the product was filtered, 499 washed with cold ethanol, and dried under high vacuum to yield $(E)-2$ 500 ((2-phenylhydrazono)methyl)pyridine ( $13.60 \mathrm{~g}$, 66\%, white crystals). ${ }^{65}$ 501 The hydrazone $(5.00 \mathrm{~g}, 25.3 \mathrm{mmol})$ was dissolved in a minimum 502 amount of DMF, and NCS $(3.58 \mathrm{~g}, 26.8 \mathrm{mmol})$ was added portion503 wise over $20 \mathrm{~min}$ and stirred for $1 \mathrm{~h}$. Water (two volume equivalents) 504 was added dropwise, and the product precipitated out of solution. The 505 solution was filtered, and the filter cake was washed thoroughly with 506 water and dried under high vacuum to yield $(Z)-N$-phenylpicolinohy507 drazonoyl chloride (4.79 g, 82\%, amorphous red solid). Mp: $125-$ $508127^{\circ} \mathrm{C} .{ }^{1} \mathrm{H} \mathrm{NMR}\left(500 \mathrm{MHz}, \mathrm{CDCl}_{3}\right) \delta 8.67(\mathrm{ddd}, J=4.9,1.8,0.9 \mathrm{~Hz}$, $5091 \mathrm{H}), 8.28(\mathrm{~s}, 1 \mathrm{H}), 8.08(\mathrm{dt}, J=8.1,1.1 \mathrm{~Hz}, 1 \mathrm{H}), 7.73$ (ddd, $J=8.1$, $5107.4,1.7 \mathrm{~Hz}, 1 \mathrm{H}), 7.37-7.30(\mathrm{~m}, 2 \mathrm{H}), 7.27$ (ddd, $J=7.4,4.9,1.1 \mathrm{~Hz}$, $5111 \mathrm{H}), 7.24-7.19(\mathrm{~m}, 2 \mathrm{H}), 6.98(\mathrm{tt}, J=7.4,1.1 \mathrm{~Hz}, 1 \mathrm{H}) .{ }^{13} \mathrm{C}$ NMR $512\left(126 \mathrm{MHz}, \mathrm{CDCl}_{3}\right) \delta 151.5,149.3,143.0,136.4,129.6,125.3,123.6$, 513 121.9, 121.3, 113.8. IR (neat) $\tilde{v}\left(\mathrm{~cm}^{-1}\right): 3147,2936,1600,1493,1236$, $5141135,845,783$. HRMS (DART) $m / z:[\mathrm{M}+\mathrm{H}]^{+}$calcd for $\mathrm{C}_{12} \mathrm{H}_{11} \mathrm{ClN}_{3}$ 515232.0642 , found 232.0642 .

516 Synthesis of $6 a$. The hydrazonoyl chloride $(2.00 \mathrm{~g}, 8.63 \mathrm{mmol})$ was 517 dissolved in methanol $(10 \mathrm{~mL})$, and $7 \mathrm{~N}$ ammonia in methanol $(9.9 \mathrm{~mL}$, $51869.1 \mathrm{mmol}$ ) was added dropwise and stirred for $4 \mathrm{~h}$. The solvent was 519 evaporated, and the residue was dissolved in ethyl acetate. The organic 520 layer was washed two times with water, followed by a brine wash, and 521 then dried over sodium sulfate. The volatiles were removed in vacuo, 522 and the resulting red oil was dried under high vacuum and crystallized 523 over multiple days $\left(1.79 \mathrm{~g}, 98 \%\right.$, red crystals). Mp: $51-55{ }^{\circ} \mathrm{C} .{ }^{1} \mathrm{H}$ $524 \operatorname{NMR}\left(500 \mathrm{MHz}, \mathrm{CDCl}_{3}\right) \delta 8.53(\mathrm{ddd}, J=4.9,1.7,1.0 \mathrm{~Hz}, 1 \mathrm{H}), 8.27$ $525(\mathrm{dt}, J=8.1,1.1 \mathrm{~Hz}, 1 \mathrm{H}), 7.72(\mathrm{ddd}, J=8.1,7.4,1.7 \mathrm{~Hz}, 1 \mathrm{H}), 7.33-$ $5267.26(\mathrm{~m}, 3 \mathrm{H}), 7.20-7.13(\mathrm{~m}, 2 \mathrm{H}), 6.89(\mathrm{t}, J=7.3 \mathrm{~Hz}, 1 \mathrm{H}), 6.43(\mathrm{~s}$, $5271 \mathrm{H}), 5.36(\mathrm{~s}, 2 \mathrm{H}) .{ }^{13} \mathrm{C}$ NMR $\left(126 \mathrm{MHz}, \mathrm{CDCl}_{3}\right) \delta 150.7,148.1$, $528147.1,146.1,136.5,129.3,129.1,124.0,121.0,120.4,114.2$. IR (neat) $529 \tilde{v}\left(\mathrm{~cm}^{-1}\right): 3423,3330,3051,1587,1495,1247,881,788$. HRMS 530 (DART) $\mathrm{m} / z$ : $[\mathrm{M}+\mathrm{H}]^{+}$calcd for $\mathrm{C}_{12} \mathrm{H}_{13} \mathrm{~N}_{4} 213.1140$, found 213.1139 . 531 Synthesis of $6 b$. The hydrazonoyl chloride $(0.20 \mathrm{~g}, 0.86 \mathrm{mmol})$ and $532 \mathrm{p}$-bromoaniline $(0.22 \mathrm{~g}, 1.29 \mathrm{mmol})$ were dissolved in THF $(2.9 \mathrm{~mL})$, 533 and triethylamine $(0.30 \mathrm{~mL}, 2.16 \mathrm{mmol})$ was added. The solution 534 was stirred for 2 days until complete by TLC. The volatiles were 535 evaporated, and the residue was dissolved in ethyl acetate and washed 536 with water and brine and then dried over sodium sulfate. The product 537 was purified by column chromatography with a gradient from hexanes 538 to $25 \%$ ethyl acetate in hexanes to yield an orange-yellow solid 539 (0.274 g, 87\%). Mp: $140-143{ }^{\circ} \mathrm{C} .{ }^{1} \mathrm{H}$ NMR (500 MHz, $\left.\mathrm{CDCl}_{3}\right) \delta$ 5408.48 (ddd, $J=4.9,1.7,1.0 \mathrm{~Hz}, 1 \mathrm{H}), 8.30(\mathrm{dt}, J=8.1,1.1 \mathrm{~Hz}, 1 \mathrm{H})$, $5417.77-7.70(\mathrm{~m}, 2 \mathrm{H}), 7.39-7.35(\mathrm{~m}, 2 \mathrm{H}), 7.29-7.25(\mathrm{~m}, 2 \mathrm{H}), 7.23$ 542 (ddd, $J=7.4,4.9,1.2 \mathrm{~Hz}, 1 \mathrm{H}), 7.12-7.08(\mathrm{~m}, 2 \mathrm{H}), 7.06($ br s, $1 \mathrm{H})$, $5436.88(\mathrm{tt}, J=7.4,1.1 \mathrm{~Hz}, 1 \mathrm{H}), 6.72-6.67(\mathrm{~m}, 2 \mathrm{H}) .{ }^{13} \mathrm{C} \mathrm{NMR}$ $544\left(126 \mathrm{MHz}, \mathrm{CDCl}_{3}\right) \delta 152.1,148.1,144.5,139.2,136.6,135.2,132.1$, $545129.4,123.2,120.6,120.1,120.0,114.1,113.2$. IR (neat) $\tilde{v}\left(\mathrm{~cm}^{-1}\right)$ : 546 3335, 2929, 1599, 1489, 1069, 878, 783. HRMS (DART) $\mathrm{m} / z$ : $[\mathrm{M}+$ $547 \mathrm{H}]^{+}$calcd for $\mathrm{C}_{18} \mathrm{H}_{16} \mathrm{BrN}_{4}$ 367.0558, found 367.0559.

548 General Procedure for the Synthesis of Boratriazaroles. 549 Hydrazonamide (1 equiv) and boronic acid (1 equiv) were dissolved 550 in toluene $(0.3 \mathrm{M})$. The reaction mixture was heated to $100{ }^{\circ} \mathrm{C}$ and 551 stirred for 6-12 h until completion, as indicated by TLC analysis. 552 Upon completion, the reaction mixture was cooled to room tem553 perature, loaded directly onto a silica gel plug, and eluted with toluene. 554 The toluene was removed in vacuo, and the product was subsequently 555 recrystallized in diethyl ether layered with hexanes to afford pure 556 product.

557 2-(3-(4-Methoxyphenyl)-2-phenyl-3,4-dihydro-2H-1,2,4,3-triaza558 borol-5-yl)pyridine (7). Scale: $0.9 \mathrm{mmol}$. Recrystallized in $\mathrm{Et}_{2} \mathrm{O}$ to 559 yield clear, colorless crystals $(126 \mathrm{mg}, 42 \%)$. Mp: $110-112{ }^{\circ} \mathrm{C} .{ }^{1} \mathrm{H}$ $560 \mathrm{NMR}\left(400 \mathrm{MHz}, \mathrm{CDCl}_{3}\right) \delta 8.60$ (ddd, $\left.J=4.9,1.7,1.0 \mathrm{~Hz}, 1 \mathrm{H}\right), 8.52$ $561(\mathrm{~s}, 1 \mathrm{H}), 8.21(\mathrm{dt}, J=8.0,1.1 \mathrm{~Hz}, 1 \mathrm{H}), 7.81-7.72(\mathrm{~m}, 1 \mathrm{H}), 7.62-7.49$ $562(\mathrm{~m}, 4 \mathrm{H}), 7.39-7.32(\mathrm{~m}, 2 \mathrm{H}), 7.29$ (ddd $J=7.5,4.9,1.2 \mathrm{~Hz}, 1 \mathrm{H}), 7.19$ $563(\mathrm{ddt}, J=8.6,6.9,1.2 \mathrm{~Hz}, 1 \mathrm{H}), 6.95-6.87(\mathrm{~m}, 2 \mathrm{H}), 3.84(\mathrm{~s}, 3 \mathrm{H}) .{ }^{13} \mathrm{C}$ $564 \mathrm{NMR}\left(126 \mathrm{MHz}, \mathrm{CDCl}_{3}\right) \delta 160.8,149.3,149.0,148.1,143.9,136.8$, $565135.3,129.0,125.1,123.7,122.7,120.4,113.9,55.2 .{ }^{11} \mathrm{~B}$ NMR $\left(128 \mathrm{MHz}, \mathrm{CDCl}_{3}\right) \delta$ 27.7. IR (neat) $\tilde{v}\left(\mathrm{~cm}^{-1}\right): 3460,3056,2932,566$ $1599,1498,1453,1412,1346,1396,1243$. HRMS (DART) $\mathrm{m} / z: 567$ $[\mathrm{M}+\mathrm{H}]^{+}$calcd for $\mathrm{C}_{19} \mathrm{H}_{17} \mathrm{BN}_{4} \mathrm{O} 329.1574$, found 329.1569 .

2-(2-Phenyl-3-(p-tolyl)-3,4-dihydro-2H-1,2,4,3-triazaborol-5-yl)- 569 pyridine (8). Scale: $0.9 \mathrm{mmol}$. Recrystallized in $\mathrm{Et}_{2} \mathrm{O} /$ hexanes to yield 570 clear, colorless crystals (58 mg, 20\%). Mp: $105-108{ }^{\circ} \mathrm{C} .{ }^{1} \mathrm{H}$ NMR 571 $\left(400 \mathrm{MHz}, \mathrm{CDCl}_{3}\right) \delta 8.60(\mathrm{dt}, J=5.1,1.4 \mathrm{~Hz}, 1 \mathrm{H}), 8.54(\mathrm{~s}, 1 \mathrm{H}), 8.22572$ $(\mathrm{dt}, J=8.0,1.1 \mathrm{~Hz}, 1 \mathrm{H}), 7.77(\mathrm{td}, J=7.8,1.7 \mathrm{~Hz}, 1 \mathrm{H}), 7.58-7.49573$ (m, 4H), 7.37-7.32 (m, 2H), 7.29 (ddd, $J=7.5,4.9,1.2 \mathrm{~Hz}, 1 \mathrm{H}), 574$ $7.21-7.15(\mathrm{~m}, 3 \mathrm{H}), 2.38(\mathrm{~s}, 3 \mathrm{H}) .{ }^{13} \mathrm{C}$ NMR $\left(126 \mathrm{MHz}, \mathrm{CDCl}_{3}\right) \delta 575$ $149.3,149.0,148.1,143.8,139.5,136.8,133.8,129.0,129.0,125.1,576$ 123.8, 122.6, 120.4, 21.7. ${ }^{11} \mathrm{~B}$ NMR $\left(128 \mathrm{MHz}, \mathrm{CDCl}_{3}\right) \delta$ 27.8. IR 577 (neat) $\tilde{v}\left(\mathrm{~cm}^{-1}\right): 3465,3054,2923,1592,1479,1459,1410,1346,806,578$ 766. HRMS (DART) $m / z:[\mathrm{M}+\mathrm{H}]^{+}$calcd for $\mathrm{C}_{19} \mathrm{H}_{17} \mathrm{BN}_{4} 313.1625,579$ found 313.1617.

2-(2,3-Diphenyl-3,4-dihydro-2H-1,2,4,3-triazaborol-5-yl)pyridine 581 (9). Scale: 0.9 mmol. Recrystallized in $\mathrm{Et}_{2} \mathrm{O} /$ hexanes to yield clear, 582 orange crystals ( $135 \mathrm{mg}, 51 \%)$. Mp: $76-78{ }^{\circ} \mathrm{C} .{ }^{1} \mathrm{H}$ NMR (400 MHz, 583 $\left.\mathrm{CDCl}_{3}\right) \delta 8.60(\mathrm{ddd}, J=4.9,1.8,1.0 \mathrm{~Hz}, 1 \mathrm{H}), 8.58(\mathrm{br} \mathrm{s}, 1 \mathrm{H}), 8.23584$ $(\mathrm{dt}, J=8.0,1.1 \mathrm{~Hz}, 1 \mathrm{H}), 7.77(\mathrm{td}, J=7.7,1.7 \mathrm{~Hz}, 1 \mathrm{H}), 7.65-7.59585$ (m, 2H), 7.58-7.52 (m, 2H), 7.44-7.32 (m, 5H), 7.30 (ddd, $J=7.5,586$ 4.9, $1.2 \mathrm{~Hz}, 1 \mathrm{H}), 7.22-7.15(\mathrm{~m}, 1 \mathrm{H}) .{ }^{13} \mathrm{C} \mathrm{NMR}\left(126 \mathrm{MHz} \mathrm{CDCl}_{3}\right) \delta 587$ $149.3,149.1,148.1,143.7,136.8,133.7,129.5,129.0,128.2,125.1,588$ 123.8, 122.6, 120.4. ${ }^{11} \mathrm{~B}$ NMR $\left(128 \mathrm{MHz}, \mathrm{CDCl}_{3}\right) \delta$ 28.0. IR (neat) 589 $\tilde{v}\left(\mathrm{~cm}^{-1}\right): 3231,2959,1596,1494,1418,1340,752,702$. HRMS 590 (DART) $\mathrm{m} / z$ : $[\mathrm{M}+\mathrm{H}]^{+}$calcd for $\mathrm{C}_{18} \mathrm{H}_{15} \mathrm{BN}_{4}$ 299.1468, found 591 299.1471.

2-(3-(4-Chlorophenyl)-2-phenyl-3,4-dihydro-2H-1,2,4,3-triaza- 593 borol-5-yl)pyridine (10). Scale: $0.47 \mathrm{mmol}$. Recrystallized in $\mathrm{Et}_{2} \mathrm{O}$ to 594 yield clear, orange crystals $(59.9 \mathrm{mg}, 38 \%) \mathrm{Mp}: 111-114{ }^{\circ} \mathrm{C} .{ }^{1} \mathrm{H} 595$ NMR $\left(500 \mathrm{MHz}, \mathrm{CDCl}_{3}\right) \delta 8.60$ (ddd, $\left.J=4.9,1.7,1.0 \mathrm{~Hz}, 1 \mathrm{H}\right), 8.59596$ (s, $1 \mathrm{H}), 8.21(\mathrm{dt}, J=8.0,1.1 \mathrm{~Hz}, 1 \mathrm{H}), 7.77$ (ddd, $J=8.0,7.5,1.7 \mathrm{~Hz}, 597$ $1 \mathrm{H}), 7.57-7.52(\mathrm{~m}, 2 \mathrm{H}), 7.52-7.48(\mathrm{~m}, 2 \mathrm{H}), 7.41-7.32(\mathrm{~m}, 4 \mathrm{H}), 598$ 7.30 (ddd, $J=7.5,4.9,1.2 \mathrm{~Hz}, 1 \mathrm{H}), 7.24-7.16(\mathrm{~m}, 1 \mathrm{H}) .{ }^{13} \mathrm{C}$ NMR 599 $\left(126 \mathrm{MHz}, \mathrm{CDCl}_{3}\right) \delta 149.4,149.1,147.9,143.5,136.9,135.8,135.1,600$ 129.1, 128.5, 125.4, 123.9, 122.6, 120.4. ${ }^{11} \mathrm{~B}$ NMR $\left(160 \mathrm{MHz}, \mathrm{CDCl}_{3}\right) 601$ $\delta$ 27.2. IR (neat) $\tilde{v}\left(\mathrm{~cm}^{-1}\right): 3456,3057,1590,1474,1343,1284,1083,602$ 813, 781. HRMS (DART) $m / z:[\mathrm{M}+\mathrm{H}]^{+}$calcd for $\mathrm{C}_{18} \mathrm{H}_{15} \mathrm{BClN}_{4} 603$ 333.1078 , found 333.1082 .

2-(3-(4-Fluorophenyl)-2-phenyl-3,4-dihydro-2H-1,2,4,3-triazabor- 605 ol-5-yl)pyridine (11). Scale: $0.9 \mathrm{mmol}$. Recrystallized in 1:1 DCM/ 606 hexanes to yield clear, orange crystals $(147 \mathrm{mg}, 50 \%)$. Mp: $112-607$ $115^{\circ} \mathrm{C} .{ }^{1} \mathrm{H}$ NMR $\left(400 \mathrm{MHz}, \mathrm{CDCl}_{3}\right) \delta 8.60$ (ddd, $J=4.9,1.8,1.0 \mathrm{~Hz}, 608$ $1 \mathrm{H}), 8.56(\mathrm{br} \mathrm{s}, 1 \mathrm{H}), 8.21(\mathrm{dt}, J=8.0,1.1 \mathrm{~Hz}, 1 \mathrm{H}), 7.77(\mathrm{ddd}, J=8.0,609$ 7.5, $1.7 \mathrm{~Hz}, 1 \mathrm{H}), 7.63-7.55(\mathrm{~m}, 2 \mathrm{H}), 7.54-7.47(\mathrm{~m}, 2 \mathrm{H}), 7.38-7.32610$ $(\mathrm{m}, 2 \mathrm{H}), 7.30(\mathrm{ddd}, J=7.5,4.9,1.2 \mathrm{~Hz}, 1 \mathrm{H}), 7.20(\mathrm{ddt}, J=7.9,6.9,611$ $1.2 \mathrm{~Hz}, 1 \mathrm{H}), 7.12-7.00(\mathrm{~m}, 2 \mathrm{H}) .{ }^{13} \mathrm{C} \mathrm{NMR}\left(126 \mathrm{MHz}^{\mathrm{CDCl}} \mathrm{CD}_{3}\right) \delta 612$ $163.9(\mathrm{~d}, J=248.9 \mathrm{~Hz}), 149.3,149.1,148.0,143.6,136.9,135.7(\mathrm{~d}, J=613$ $7.7 \mathrm{~Hz}), 129.1,125.3,123.9,122.7,120.4,115.4(\mathrm{~d}, J=20.1 \mathrm{~Hz}) .{ }^{11} \mathrm{~B} 614$ NMR $\left(128 \mathrm{MHz}, \mathrm{CDCl}_{3}\right) \delta 27.7 .{ }^{19} \mathrm{~F}$ NMR $\left(377 \mathrm{MHz}^{\left.-\mathrm{CDCl}_{3}\right) \delta 615}\right.$ -110.9. IR (neat) $\tilde{v}\left(\mathrm{~cm}^{-1}\right): 3451,3054,1596,1496,1413,1342,1214,616$ 837, 767. HRMS (DART) $m / z$ : $[\mathrm{M}+\mathrm{H}]^{+}$calcd for $\mathrm{C}_{18} \mathrm{H}_{14} \mathrm{BFN}_{4} 617$ 317.1374, found 317.1376 .

4-(2-Phenyl-5-(pyridin-2-yl)-2,4-dihydro-3H-1,2,4,3-triazaborol-3- 619 yl)benzonitrile (12). Scale: 0.47 mmol. Recrystallized in $\mathrm{Et}_{2} \mathrm{O}$ to yield 620 clear, pale orange crystals $(96.3 \mathrm{mg}, 63 \%)$. Mp: $126-128{ }^{\circ} \mathrm{C} .{ }^{1} \mathrm{H}$ NMR 621 $\left(500 \mathrm{MHz}, \mathrm{CDCl}_{3}\right) \delta 8.70($ br s, $1 \mathrm{H}), 8.60$ (ddd, $J=4.9,1.7,1.0 \mathrm{~Hz}, 622$ $1 \mathrm{H}), 8.22(\mathrm{dt}, J=8.0,1.1 \mathrm{~Hz}, 1 \mathrm{H}), 7.79(\mathrm{ddd}, J=8.0,7.5,1.7 \mathrm{~Hz}, 1 \mathrm{H}), 623$ $7.73-7.68(\mathrm{~m}, 2 \mathrm{H}), 7.67-7.61(\mathrm{~m}, 2 \mathrm{H}), 7.50-7.43(\mathrm{~m}, 2 \mathrm{H}), 7.40-624$ $7.34(\mathrm{~m}, 2 \mathrm{H}), 7.32$ (ddd, $J=7.5,4.9,1.2 \mathrm{~Hz}, 1 \mathrm{H}), 7.25-7.21(\mathrm{~m}, 1 \mathrm{H}) .625$ ${ }^{13} \mathrm{C}$ NMR $\left(126 \mathrm{MHz}, \mathrm{CDCl}_{3}\right) \delta 149.6,149.1,147.7,143.1,137.0,626$ 134.2, 131.6, 129.2, 125.7, 124.1, 122.7, 120.4, 119.0, 113.1. ${ }^{11}$ B NMR 627 $\left(160 \mathrm{MHz}, \mathrm{CDCl}_{3}\right) \delta$ 26.9. IR (neat) $\tilde{v}\left(\mathrm{~cm}^{-1}\right): 3272,2927,2166,628$ 1600, 1494, 1341, 1091, 832, 765. HRMS (DART) $m / z:[\mathrm{M}+\mathrm{H}]^{+} 629$ calcd for $\mathrm{C}_{19} \mathrm{H}_{15} \mathrm{BN}_{5} 324.1421$, found 324.1430.

630

2-(3-(2,6-Difluorophenyl)-2-phenyl-3,4-dihydro-2H-1,2,4,3-triaza- 631 borol-5-yl)pyridine (13). Scale: $0.471 \mathrm{mmol}$. Recrystallized in $\mathrm{Et}_{2} \mathrm{O} / 632$ hexanes to yield clear, off-white crystals $(50 \mathrm{mg}, 32 \%)$. Mp: $110-633$ $113{ }^{\circ} \mathrm{C} .{ }^{1} \mathrm{H}$ NMR $\left(500 \mathrm{MHz}, \mathrm{CDCl}_{3}\right) \delta 8.76(\mathrm{~s}, 1 \mathrm{H}), 8.60$ (ddd, $J=634$ 4.9, 1.8, $1.0 \mathrm{~Hz}, 1 \mathrm{H}), 8.24(\mathrm{dt}, J=8.0,1.1 \mathrm{~Hz}, 1 \mathrm{H}), 7.78$ (ddd, $J=8.0,635$ 
$6367.5,1.7 \mathrm{~Hz}, 1 \mathrm{H}), 7.52-7.45(\mathrm{~m}, 2 \mathrm{H}), 7.41(\mathrm{tt}, J=8.3,6.7 \mathrm{~Hz}, 1 \mathrm{H})$, $6377.35-7.28(\mathrm{~m}, 3 \mathrm{H}), 7.21-7.13(\mathrm{~m}, 1 \mathrm{H}), 6.99-6.85(\mathrm{~m}, 2 \mathrm{H}) .{ }^{13} \mathrm{C}$ 638 NMR $\left(126 \mathrm{MHz}, \mathrm{CDCl}_{3}\right) \delta 165.3(\mathrm{dd}, J=247.3,12.6 \mathrm{~Hz}), 149.8$, $639149.1,147.8,143.8,136.9,132.5(\mathrm{t}, J=10.3 \mathrm{~Hz}), 128.9,125.0,123.9$, $640121.1,120.4,112.4-110.7(\mathrm{~m}) .{ }^{11} \mathrm{~B}$ NMR $\left(160 \mathrm{MHz}, \mathrm{CDCl}_{3}\right) \delta 24.5$. $641{ }^{19} \mathrm{~F}$ NMR $\left(376 \mathrm{MHz}, \mathrm{CDCl}_{3}\right) \delta$-99.9. IR (neat) $\tilde{v}\left(\mathrm{~cm}^{-1}\right): 3234$, 642 2928, 1596, 1500, 1343, 1227, 1118, 1105, 982, 785. HRMS (DART) $643 \mathrm{~m} / z:[\mathrm{M}+\mathrm{H}]^{+}$calcd for $\mathrm{C}_{18} \mathrm{H}_{14} \mathrm{BF}_{2} \mathrm{~N}_{4}$ 335.1280, found 335.1286. 644 2-(4-(4-Bromophenyl)-3-(2,6-difluorophenyl)-2-phenyl-3,4-dihy645 dro-2H-1,2,4,3-triazaborol-5-yl)pyridine (14). Scale: $0.272 \mathrm{mmol}$. 646 Recrystallized in $\mathrm{Et}_{2} \mathrm{O}$ /hexanes to yield clear, pale yellow crystals 647 (83.3 mg, 63\%). Mp: $160-163{ }^{\circ} \mathrm{C} .{ }^{1} \mathrm{H}$ NMR $\left(500 \mathrm{MHz}, \mathrm{CDCl}_{3}\right) \delta$ 6488.43 (ddd, $J=4.8,1.8,1.0 \mathrm{~Hz}, 1 \mathrm{H}), 7.80(\mathrm{dt}, J=7.9,1.1 \mathrm{~Hz}, 1 \mathrm{H}), 7.71$ 649 (ddd, $J=7.6,1.8 \mathrm{~Hz}, 1 \mathrm{H}), 7.49-7.44(\mathrm{~m}, 2 \mathrm{H}), 7.35$ (ddd, $J=8.3,6.8$, $6501.6 \mathrm{~Hz}, 1 \mathrm{H}), 7.31-7.26(\mathrm{~m}, 4 \mathrm{H}), 7.22(\mathrm{ddd}, J=7.6,4.8,1.2 \mathrm{~Hz}, 1 \mathrm{H})$, $6517.16-7.11(\mathrm{~m}, 1 \mathrm{H}) .{ }^{13} \mathrm{C}$ NMR $\left(126 \mathrm{MHz}, \mathrm{CDCl}_{3}\right) \delta 164.8(\mathrm{dd}, J=$ $652245.8,12.5 \mathrm{~Hz}), 149.4,149.3,148.7,142.9,138.6,136.6,132.7(\mathrm{t}, J=$ $65310.1 \mathrm{~Hz}), 131.8,129.1,128.2,125.2,124.3,123.6,120.7,120.1,111.7-$ $654111.1(\mathrm{~m}) .{ }^{11} \mathrm{~B}$ NMR $\left(160 \mathrm{MHz}, \mathrm{CDCl}_{3}\right) \delta 25.7 .{ }^{19} \mathrm{~F}$ NMR $(470 \mathrm{MHz}$, $\left.655 \mathrm{CDCl}_{3}\right) \delta$-99.9. IR (neat) $\tilde{v}\left(\mathrm{~cm}^{-1}\right): 2927,1621,1489,1381,1350$, $6561258,1228,1066,834,788$. HRMS (DART) $\mathrm{m} / z$ : $[\mathrm{M}+\mathrm{H}]^{+}$calcd for $657 \mathrm{C}_{24} \mathrm{H}_{17} \mathrm{BBrF}_{2} \mathrm{~N}_{4} 489.0698$, found 489.0705 .

\section{ASSOCIATED CONTENT}

659 S Supporting Information

660 The Supporting Information is available free of charge on the 661 ACS Publications website at DOI: 10.1021/acs.joc.6b01565.

662 Computational data, X-ray crystallographic data, and ${ }^{1} \mathrm{H}$, ${ }_{663}{ }^{13} \mathrm{C},{ }^{11} \mathrm{~B},{ }^{19} \mathrm{~F}$ NMR spectra (PDF)

664 X-ray crystallographic data for 7 (CCDC 1485646) (CIF) 665 X-ray crystallographic data for 12 (CCDC 1485647) (CIF) 666 X-ray crystallographic data for 13 (CCDC 1485644) (CIF) 667 X-ray crystallographic data for 14 (CCDC 1485645) (CIF)

\section{AUTHOR INFORMATION}

\section{Corresponding Authors}

670 *E-mail: dseferos@chem.utoronto.ca.

671 *E-mail: ayudin@chem.utoronto.ca.

672 Notes

673 The authors declare no competing financial interest.

\section{ACKNOWLEDGMENTS}

675 We gratefully acknowledge the Natural Science and Engineer676 ing Research Council (NSERC) for financial support. S.K.L. 677 thanks NSERC CGS-D and the Walter Sumner Foundation for 678 funding. The authors also acknowledge NSERC and the 679 Canadian Foundation for Innovation, Project Number 19119, 680 and the Ontario Research Fund for funding of the Centre for 681 Spectroscopic Investigation of Complex Organic Molecules and 682 Polymers. A. Lough is thanked for X-ray structural analysis.

\section{$683 \square$ REFERENCES}

684 (1) Review: Wang, B. J.; Groziak, M. P. Adv. Heterocycl. Chem. 2016, $685118,47-90$ and references therein.

686 (2) Synthesis and Application of Organoboron Compounds; Fernández, 687 E., Whiting, A., Eds.; Springer: New York, 2015.

688 (3) Liu, Z.; Marder, T. B. Angew. Chem., Int. Ed. 2008, 47, 242-244. 689 (4) Review: Bosdet, M. J. D.; Piers, W. E. Can. J. Chem. 2009, 87, 869029 and references therein.

691 (5) Review: Campbell, P. G.; Marwitz, A. J. V.; Liu, S.-Y. Angew. 692 Chem., Int. Ed. 2012, 51, 6074-6092 and references therein.

693 (6) Bosdet, M. J. D.; Jaska, C. A.; Piers, W. E.; Sorensen, T. S.; 694 Parvez, M. Org. Lett. 2007, 9, 1395-1398.

695 (7) Jaska, C. A.; Piers, W. E.; McDonald, R.; Parvez, M. J. Org. Chem. $6962007,72,5234-5243$.
(8) Baggett, A. W.; Guo, F.; Li, B.; Liu, S.-Y.; Jäkle, F. Angew. Chem., 697 Int. Ed. 2015, 54, 11191-11195. 698

(9) Liu, L.; Marwitz, A. J. V.; Matthews, B. W.; Liu, S.-Y. Angew. 699 Chem., Int. Ed. 2009, 48, 6817-6819. 700

(10) Stock, A.; Pohland, E. Chem. Ber. 1926, 59, 2215-2223. 701

(11) Ruman, T.; Jarmula, A.; Rode, W. Bioorg. Chem. 2010, 38, 242- 702 245.

(12) Shi, Y.-G.; Yang, D.-T.; Mellerup, S. K.; Wang, N.; Peng, T.; 704 Wang, S. Org. Lett. 2016, 18, 1626-1629. 705

(13) Huang, H.; Pan, Z.; Cui, C. Chem. Commun. 2016, 52, 4227- 706 4230 .

(14) Ulmschneider, D.; Goubeau, J. Chem. Ber. 1957, 90, 2733- 708 2738.

(15) Pailer, M.; Huemer, H. Monatsh. Chem. 1964, 95, 373-378. 710

(16) Dornow, A.; Fischer, K. Chem. Ber. 1966, 99, 68-71. 711

(17) Paetzold, P. I.; Stohr, G. Chem. Ber. 1968, 101, 2874-2880. 712

(18) Yale, H. L. J. Heterocycl. Chem. 1971, 8, 205-208. 713

(19) Goel, A. B.; Gupta, V. D. J. Organomet. Chem. 1974, 77, 183- 714 188.

(20) Ashe, A. J., III; Fang, X.; Fang, X.; Kampf, J. W. Organometallics 716 2001, 20, 5413-5418.

(21) Dürüst, Y.; Dürüst, N.; Akcan, M. J. Chem. Eng. Data 2007, 52, 718 718-720.

(22) Dürüst, Y.; Akcan, M.; Martiskainen, O.; Siirola, E.; Pihlaja, K. 720 Polyhedron 2008, 27, 999-1007.

(23) Weber, L. Coord. Chem. Rev. 2008, 252, 1-31.

(24) Abbey, E. R. Zakharov, L. N.; Liu, S.Y. J. Am. Chem. Soc. 2010, 132, 16340-16342.

(25) Abbey, E. R.; Zakharov, L. N.; Liu, S.-Y. J. Am. Chem. Soc. 2011, 725 133, 11508-11511. 726

(26) Chrostowska, A.; Xu, S.; Mazière, A.; Boknevitz, K.; Li, B.; 727 Abbey, E. R.; Dargelos, A.; Graciaa, A.; Liu, S.-Y. J. Am. Chem. Soc. 728 2014, 136, 11813-11820.

(27) Davies, G. H. M.; Molander, G. A. J. Org. Chem. 2016, 81, 730 3771-3779.

(28) Paetzold, P. I. Z. Anorg. Allg. Chem. 1963, 326, 64-69. 732

(29) Dewar, M. J. S.; Golden, R.; Spanninger, P. A. J. Am. Chem. Soc. 733 1971, 93, 3298-3299.

(30) Dewar, M. J. S.; Spanninger, P. A. Tetrahedron 1972, 28, 959- 735 961.

(31) Zurwerra, D.; Quetglas, V.; Kloer, D. P.; Renold, P.; Pitterna, T. 737 Org. Lett. 2015, 17, 74-77.

(32) Lu, W.; Hu, H.; Li, Y.; Ganguly, R.; Kinjo, R. J. Am. Chem. Soc. 739 2016, 138, 6650-6661. 740

(33) Loh, Y. K.; Chong, C. C.; Ganguly, R.; Li, Y.; Vidovic, D.; Kinjo, 741 R. Chem. Commun. 2014, 50, 8561-8564. 742

(34) Adachi, S.; Liew, S. K.; Lee, C. F.; Lough, A.; He, Z.; St. Denis, 743 J. D.; Poda, G.; Yudin, A. K. Org. Lett. 2015, 17, 5594-5597. 744

(35) Weber, L.; Schnieder, M.; Stammler, H.-G.; Neumann, B.; 745 Schoeller, W. W. Eur. J. Inorg. Chem. 1999, 1999, 1193-1198. 746

(36) Chang, M.-C.; Otten, E. Organometallics 2016, 35, 534-542. 747

(37) Avramenko, G. V.; Bezuglaya, Z. V.; Stepanov, B. I.; Troitskaya, 748 V. S.; Vinokurov, V. G. J. Appl. Spectrosc. 1988, 48, 620-624. 749

(38) Bioactive Heterocyclic Compound Classes, Agrochemicals and 750 Pharamceuticals; Lamberth, C., Dinges, J., Eds.; Wiley-VCH: 751 Weinheim, 2012. 752 (39) Kreuer, K. D.; Fuchs, A.; Ise, M.; Spaeth, M.; Maier, J. 753 Electrochim. Acta 1998, 43, 1281-1288. 754

(40) Taydakov, I. V.; Akkuzina, A. A.; Avetisov, R. I.; Khomyakov, A. 755 V.; Saifutyarov, R. R.; Avetissov, I. C. J. Lumin. 2016, 177, 31-39. 756

(41) Handa, N. V.; Li, S.; Gerbec, J. A.; Sumitani, N.; Hawker, C. J.; 757 Klinger, D. J. Am. Chem. Soc. 2016, 138, 6400-6403. 758

(42) Liu, X.; Zhang, Y.; Li, B.; Zakharov, L. N.; Vasiliu, M.; Dixon, D. 759 A.; Liu, S.-Y. Angew. Chem., Int. Ed. 2016, 55, 8333-8337. 760

(43) Hatakeyama, T.; Hashimoto, S.; Seki, S.; Nakamura, M. J. Am. 761 Chem. Soc. 2011, 133, 18614-18617. 762

(44) Paulvannan, K.; Hale, R.; Sedehi, D.; Chen, T. Tetrahedron 763 2001, 57, 9677-9682. 
765 (45) Ahmed, S.; Longchar, M.; Boruah, R. C. Indian J. Chem. Sec. B $7661999,38,125-127$.

767 (46) Li, J.; Neuville, L. Org. Lett. 2013, 15, 1752-1755.

768 (47) Crouch, R. D.; Howard, J. L.; Zile, J. L.; Barker, K. H. J. Chem. 769 Educ. 2006, 83, 1658-1660.

770 (48) Buck, C.; Gramlich, B.; Wagner, S. 2015, arXiv:150902327v1. 771 arXiv.org e-Print archive (Accessed May 28, 2016). https://arxiv.org/ 772 abs/1509.02327v1.

773 (49) Fery-Forgues, S.; Lavabre, D. J. Chem. Educ. 1999, 76, 12607741264

775 (50) Consistent with literature value of Lophine $5\left(\Phi_{\mathrm{F}}=0.27\right)$ : 776 Fridman, N.; Kaftory, M.; Speiser, S. Sens. Actuators B 2007, 126, 107777115.

778 (51) Frisch, M. J.; Trucks, G. W.; Schlegel, H. B.; Scuseria, G. E.; 779 Robb, M. A.; Cheeseman, J. R.; Scalmani, G.; Barone, V.; Mennucci, 780 B.; Petersson, G. A.; Nakatsuji, H.; Caricato, M.; Li, X.; Hratchian, H. 781 P.; Izmaylov, A. F.; Bloino, J.; Zheng, G.; Sonnenberg, J. L.; Hada, M.; 782 Ehara, M.; Toyota, K.; Fukuda, R.; Hasegawa, J.; Ishida, M.; Nakajima, 783 T.; Honda, Y.; Kitao, O.; Nakai, H.; Vreven, T.; Montgomery, J. A., Jr; 784 Peralta, J. E.; Ogliaro, F.; Bearpark, M.; Heyd, J. J.; Brothers, E.; Kudin, 785 K. N.; Staroverov, V. N.; Kobayashi, R.; Normand, J.; Raghavachari, K.; 786 Rendell, A.; Burant, J. C.; Iyengar, S. S.; Tomasi, J.; Cossi, M.; Rega, 787 N.; Millam, J. M.; Klene, M.; Knox, J. E.; Cross, J. B.; Bakken, V.; 788 Adamo, C.; Jaramillo, J.; Gomperts, R.; Stratmann, R. E.; Yazyev, O.; 789 Austin, A. J.; Cammi, R.; Pomelli, C.; Ochterski, J. W.; Martin, R. L.; 790 Morokuma, K.; Zakrzewski, V. G.; Voth, G. A.; Salvador, P.; 791 Dannenberg, J. J.; Dapprich, S.; Daniels, A. D.; Farkas, O.; 792 Foresman, J. B.; Ortiz, J. V.; Cioslowski, J.; Fox, D. J. Gaussian 09, 793 revision D.01; Gaussian, Inc.: Wallingford, CT, 2009.

794 (52) Chen, Z.; Wannere, C. S.; Corminboeuf, C.; Puchta, R.; 795 Schleyer, P. V. R. Chem. Rev. 2005, 105, 3842-3888.

796 (53) We did not follow up with attempts to attain X-ray data for 797 compound $\mathbf{1 2}$ in its pure form as we still obtained the pertinent 798 structural data. The reaction was repeated with a longer reaction time 799 followed by recrystallization for full characterization and used for 800 subsequent analyses.

801 (54) Wu, Y.-Y.; Chen, Y.; Gou, G.-Z.; Mu, W.-H.; Lv, X.-J.; Du, M.802 L.; Fu, W.-F. Org. Lett. 2012, 14, 5226-5229.

803 (55) Gibson, G. L.; McCormick, T. M.; Seferos, D. S. J. Am. Chem. 804 Soc. 2012, 134, 539-547.

805 (56) Gibson, G. L.; McCormick, T. M.; Seferos, D. S. J. Phys. Chem. 806 C 2013, 117, 16606-16615.

807 (57) Taniguchi, T.; Yamaguchi, S. Organometallics 2010, 29, 57328085735.

809 (58) Abbey, E. R.; Zakharov, L. N.; Liu, S.-Y. J. Am. Chem. Soc. 2008, $810130,7250-7252$.

811 (59) Sasaki, S.; Drummen, G. P. C.; Konishi, G.-I. J. Mater. Chem. C 812 2016, 4, 2731-2743.

813 (60) O’Brien, M.; Koos, P.; Browne, D. L.; Ley, S. V. Org. Biomol. 814 Chem. 2012, 10, 7031-7036.

815 (61) Sibi, M. P.; Stanley, L. M.; Soeta, T. Adv. Synth. Catal. 2006, $816348,2371-2375$.

817 (62) Paulvannan, K.; Chen, T.; Hale, R. Tetrahedron 2000, 56, 80718188076.

819 (63) Zhang, T.; Bao, W. J. Org. Chem. 2013, 78, 1317-1322.

820 (64) Chen, C.-Y.; Hu, W.-P.; Yan, P.-C.; Senadi, G. C.; Wang, J.-J. 821 Org. Lett. 2013, 15, 6116-6119.

822 (65) Chaur, M. N.; Collado, D.; Lehn, J.-M. Chem. - Eur. J. 2011, 17, $823248-258$. 